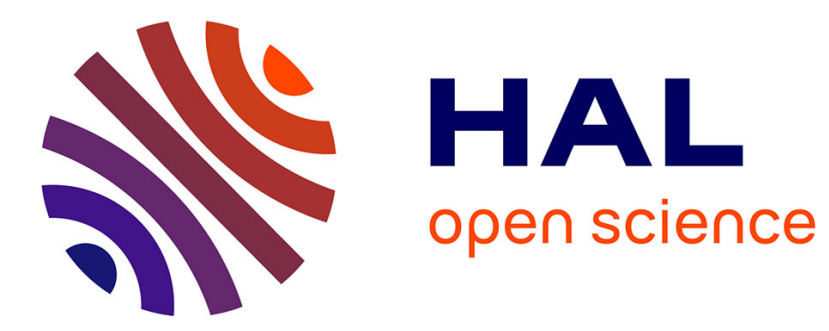

\title{
Calix[6]arene Tris-carboxylic Acid Derivatives: X-ray and NMR Characterization of their Remarkable Host-guest Properties Toward Ammonium Ions
}

Ivan Jabin, Stéphane Le Gac, Michel Giorgi

\section{- To cite this version:}

Ivan Jabin, Stéphane Le Gac, Michel Giorgi. Calix[6]arene Tris-carboxylic Acid Derivatives: Xray and NMR Characterization of their Remarkable Host-guest Properties Toward Ammonium Ions. Supramolecular Chemistry, 2007, 19 (03), pp.185-197. 10.1080/10610270600967038 . hal-00513488

\author{
HAL Id: hal-00513488 \\ https://hal.science/hal-00513488
}

Submitted on 1 Sep 2010

HAL is a multi-disciplinary open access archive for the deposit and dissemination of scientific research documents, whether they are published or not. The documents may come from teaching and research institutions in France or abroad, or from public or private research centers.
L'archive ouverte pluridisciplinaire HAL, est destinée au dépôt et à la diffusion de documents scientifiques de niveau recherche, publiés ou non, émanant des établissements d'enseignement et de recherche français ou étrangers, des laboratoires publics ou privés. 


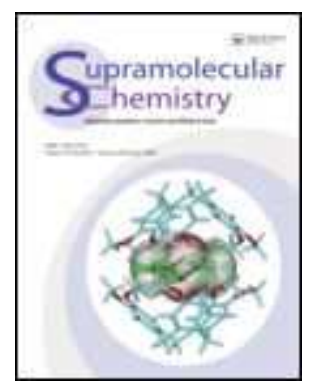

\section{Calix[6]arene Tris-carboxylic Acid Derivatives: $X$-ray and NMR Characterization of their Remarkable Host-guest Properties Toward Ammonium Ions}

\begin{tabular}{|c|c|}
\hline Journal: & Supramolecular Chemistry \\
\hline Manuscript ID: & GSCH-2006-0019.R2 \\
\hline Manuscript Type: & Full Paper \\
\hline $\begin{array}{r}\text { Date Submitted by the } \\
\text { Author: }\end{array}$ & 11-Aug-2006 \\
\hline Complete List of Authors: & $\begin{array}{l}\text { Jabin, Ivan; Université du Havre, URCOM } \\
\text { Le Gac, Stéphane; Université du Havre } \\
\text { Giorgi, Michel; Université Paul Cézanne(Aix-Marseille III) }\end{array}$ \\
\hline Keywords: & $\begin{array}{l}\text { Calix[6]arene, Ammonium ions, Supramolecular Chemistry, } \\
\text { Molecular Receptor, Host-guest Systems }\end{array}$ \\
\hline \multicolumn{2}{|c|}{$\begin{array}{l}\text { Note: The following files were submitted by the author for peer review, but cannot be converted } \\
\text { to PDF. You must view these files (e.g. movies) online. }\end{array}$} \\
\hline $\begin{array}{l}\text { Figure 1.cdx } \\
\text { Scheme 1.cdx } \\
\text { Scheme 2.cdx } \\
\text { Scheme 3.cdx }\end{array}$ & \\
\hline
\end{tabular}

\section{S) ScholarONE \\ Manuscript Central}




\title{
Calix[6]arene Tris-carboxylic Acid Derivatives: X-ray and NMR \\ Characterization of their Remarkable Host-guest Properties \\ Toward Ammonium Ions
}

\author{
Stéphane Le Gac, ${ }^{a}$ Michel Giorgi ${ }^{b}$ and Ivan Jabin ${ }^{a *}$ \\ ${ }^{a}$ Unité de Recherche en Chimie Organique et Macromoléculaire, Université du Havre, FST, \\ 25 rue Philippe Lebon, BP 540, 76058 Le Havre cedex, France; ${ }^{b}$ Laboratoire de \\ Cristallochimie, Université Paul Cézanne (Aix-Marseille III), Centre Scientifique Saint- \\ Jérôme, av. Escadrille Normandie-Niemen, 13397 Marseille cedex 20, France \\ *Corresponding author. E-mail: ivan.jabin@univ-lehavre.fr
}

Abbreviated title for running headlines: Calix[6]tris-carboxylic acid receptors for ammonium ions

KEYWORDS: Calix[6]arene / Ammonium ions / Supramolecular Chemistry / Molecular Receptor / Host-guest Systems.

\begin{abstract}
The ability of calix[6]arene tris-carboxylic acid derivatives to include ammonium guests has been investigated both in solution and in the solid state. NMR studies and crystallographic data showed that the highly flexible calix[6]arene structures can be shaped in a well defined cone conformation thanks to the formation of an ion-paired cap between the carboxylate
\end{abstract}


groups of the calixarene and their ammonium counter-ions. The resulting supramolecular edifices exhibit remarkable host-guest properties toward ammonium ions even in polar and protic solvents. The recognition process has been rationalized in the solid state by the combination of hydrogen bonding, electrostatic and $\mathrm{CH}-\pi$ interactions, and a remarkable $\mathrm{C}_{3^{-}}$ complementarity between the well-organized binding carboxylates of the host and the ammonium guest. Very interestingly, the endo-cavity complexation of large polycyclic ammonium ions as well as bioactive ammonium ions has been clearly demonstrated through NMR spectroscopy. Finally, the tuning of the nature of the ammonium ions involved in the supramolecular cap led to highly responsive molecular receptors.

\section{Introduction}

The recognition of ammonium ions by synthetic receptors ${ }^{1}$ is a topic of great interest since it can lead to a better understanding of biological recognition processes and to the development of efficient sensors toward bioactive molecules. ${ }^{2}$ Calix[6]arenes ${ }^{3}$ are attractive cavity-shaped platforms for the design of such hosts. ${ }^{4}$ Indeed, the introduction of a binding site devoted to ammonium ions can be readily achieved through the alkylation of their phenolic units with appropriate functional groups and, in contrast to the smaller calix[4]arenes, the size of their cavity is suitable for the deep inclusion of relatively large organic molecules. However, the host-guest properties of calix[6]arenes toward ammonium ions were scarcely studied. This is mainly due to their high conformational flexibility which usually needs to be restricted in order to obtain receptors with a well-defined cavity. ${ }^{5}$ Thus, only a few examples of calix[6]arenes bearing ester ${ }^{6}$ groups as well as crown ether ${ }^{7}$ or aza-cryptand ${ }^{8}$ units have been described. ${ }^{9}$ With such receptors, the host-guest recognition may involve $\pi$-cationic, $\mathrm{CH}-\pi, \pi-\pi$ interactions and hydrogen-bonding. The use of electrostatic interactions for the binding of ammonium ions by calix[6]arene hosts was also reported. ${ }^{10,11}$ Notably, the extraction ability 
of organo-soluble $t$ Octyl-calix[6] arene hexa-acetic acid derivatives toward biological amino compounds such as nucleobases, amino acids or catecholamines was recently studied ${ }^{12}$ but the nature of the host-guest adducts remained unclear and the endo-cavity complexation of the ammonium ions was not evidenced.

We have shown that the conformational behaviour of calix[6]arenes can be controlled by the grafting of three ammonium arms on their narrow rim. ${ }^{13}$ The resulting calix[6]trisammoniums are constrained in cone conformation through an ion-paired cap formed by the assembly of their cationic arms and the counter-anions. In organic media, these simple polarized hosts behave as remarkable endo-receptors since, besides its structural role, the supramolecular cap provides an efficient binding site for polar neutral guests through chargedipole interactions and hydrogen bonding (Figure 1, left). In order to design calix[6]arene based receptors able to include ammonium ions in their cavity, we were interested in studying the opposite way for the rigidification of the calixarene core, i.e. an ion-paired cap consisting in three carboxylate arms and their counter-cations. With such poly-carboxylate receptors, strong electrostatic interactions were notably expected for the stabilization of the host-guest adducts. ${ }^{14}$ Our first aim was to contribute to the understanding of the factors which govern the recognition of ammonium ions by poly-anionic hosts possessing a hydrophobic cavity. On the other hand, we wanted to study the feasibility of developing simple and efficient sensors for biologically important ammonium ions.

In the present work, we describe the remarkable host-guest properties of calix[6]tris-acid derivatives $\mathbf{1}^{15}$ and $\mathbf{2}^{16}$ (Figure 1, right) toward ammonium ions. In contrast to $\mathbf{1}$, the open cavity of calix[6]tris-acid $\mathbf{2}$ was expected to allow the inclusion of large ammonium guests. 


\section{Results}

\section{${ }^{1}$ H NMR study of the host-guest properties of calix[6]tris-acid 1 toward ammonium ions.}

First, the ability of calix[6](COOH) $)_{3} 1$ (Figure 2a) to host small ammonium ions $\mathrm{R}^{\prime} \mathrm{NH}_{3}{ }^{+}$ (with $\mathrm{R}^{\prime}=\mathrm{Et}$ and Pr) was investigated by ${ }^{1} \mathrm{H}$ NMR spectroscopy at $294 \mathrm{~K}$. Thus, the addition of 1 equiv. of $\mathrm{R}^{\prime} \mathrm{NH}_{2}$ into a $\mathrm{CDCl}_{3}$ solution of 1 led to a broadening of its NMR signals and the formation of a new species displaying signals below $0 \mathrm{ppm}$ (Figure $2 \mathrm{~b}$ with $\mathrm{R}^{\prime}=\mathrm{Pr}$ ). These high-field resonances suggest the endo-cavity complexation of a $\mathrm{R}^{\prime} \mathrm{NH}_{3}{ }^{+}$molecule formed by deprotonation of the $\mathrm{COOH}$ groups of the host 1 . With 2 equiv. of $\mathrm{R}^{\prime} \mathrm{NH}_{2}$, all the NMR signals sharpened and the new species remained the only one observable in solution. It displayed a $C_{3 \mathrm{v}}$-symmetrical profile characteristic of the endo-complexes $\mathbf{1}^{-\mathbf{2 H +}, \mathbf{R}^{\prime} \mathbf{N H 3}^{+}} \supset \mathbf{R}^{\prime} \mathbf{N H}_{\mathbf{3}}{ }^{+}$ (Figure 2c with $\mathrm{R}^{\prime}=\mathrm{Pr}$, Scheme 1). Indeed, beside the resonances of the host and one equivalent of exo- $\mathrm{R}^{\prime} \mathrm{NH}_{3}{ }^{+17}$ high-field signals show the strong binding ${ }^{18}$ of exactly one equiv. of the $\mathrm{R}^{\prime} \mathrm{NH}_{3}{ }^{+}$guest in the heart of the calixarene cavity $\left(\delta_{\mathrm{CH} 3}=-1.38\right.$ and $-1.75 \mathrm{ppm}$ for $\mathrm{R}^{\prime}$ 
$=$ Et and Pr respectively). In contrast to calix $[6](\mathrm{COOH})_{3}$ 1, the endo-complexes $\mathbf{1}^{-}$ ${ }^{2 \mathbf{H}+, \mathbf{R}^{\prime} \mathbf{N H 3}^{+}}{ } \mathbf{R}^{\prime} \mathbf{N H}_{3}{ }^{+}$possess two sharp doublets for the ArCH $\mathrm{H}_{2}$ methylene protons, showing a cone-cone inversion of their calixarene skeleton that is slower than the NMR time scale. Moreover, both their $\mathrm{Ar} H$ and $t \mathrm{Bu}$ signals are largely differentiated $\left(0.68<\Delta \delta_{\mathrm{ArH}}<0.78\right.$ and $0.59<\Delta \delta_{\mathrm{tBu}}<0.64 \mathrm{ppm}$ ) while those of 1 are characteristic of a straight cone conformation $\left(\Delta \delta_{\mathrm{ArH}}=0.05\right.$ and $\Delta \delta_{\mathrm{tBu}}=0.04 \mathrm{ppm}$, see the structure displayed in Figure 1). All these NMR data clearly indicate that, upon complexation of the ammonium guest, the calixarene structure of $\mathbf{1}^{-2 \mathrm{H}+}$ adopts a more rigid and flattened cone conformation with the methoxy groups expelled toward the outside of the cavity $\left(\delta_{\mathrm{OMe}}=3.82\right.$ and $3.85 \mathrm{ppm}$ for $\mathrm{R}^{\prime}=\mathrm{Et}$ and $\mathrm{Pr}$ respectively) (See the insert displayed in Scheme 1). The addition of a third equiv. of $\mathrm{R}^{\prime} \mathrm{NH}_{2}$ led to a high-field shift of the $\mathrm{CH}_{2} \mathrm{COO}$ signal of the calixarene host (from 4.42 for $\mathbf{1}^{\mathbf{2}} \mathbf{H +}$ to $4.34 \mathrm{ppm}$ for $\mathbf{1}^{-3 \mathrm{H}+}$ in the case of $\mathrm{R}^{\prime}=\operatorname{Pr}$ for instance $)^{19}$ indicating the total deprotonation of the carboxylic groups and thus the formation of the endo-complexes $\mathbf{1}^{-\mathbf{3 H +}+\mathbf{2} \mathbf{R}^{\prime} \mathbf{N H}^{+}} \supset \mathbf{R}^{\prime} \mathbf{N H}_{\mathbf{3}}{ }^{+}$ (Figure $2 \mathrm{~d}$ with $\mathrm{R}^{\prime}=\mathrm{Pr}$, Scheme 1$){ }^{20}$ Indeed, the $\mathrm{CH}_{2} \mathrm{COO}$ resonance did not change upon the subsequent addition of a large excess of $\mathrm{R}^{\prime} \mathrm{NH}_{2}$. Surprisingly, the addition of picrate salts of either ethylammonium or propylammonium (i.e. $\mathrm{EtNH}_{3}{ }^{+}, \mathrm{Pic}^{-}$or $\mathrm{PrNH}_{3}{ }^{+}, \mathrm{Pic}^{-}$) to a $\mathrm{CDCl}_{3}$ solution of $\mathbf{1}$ also led to their inclusion and two equiv. of ammonium ions were needed for the formation of the endo-complexes $\mathbf{1}^{\mathbf{R}}{ }^{\prime}{ }^{+}{ }^{2} \mathbf{R}^{\prime} \mathbf{N H}_{3}{ }^{+}, \mathbf{2 P i c}^{-}$(with $\mathrm{R}^{\prime}=$ Et or Pr) as the only observable species (Scheme 1). It is noteworthy that the ethyl ester and primary amide derivatives of 1 [i.e. calix[6](COOEt $)_{3}$ and calix[6]( $\left.\mathrm{CONH}_{2}\right)_{3}$ ] were unable to include these ammonium ions under similar conditions. Finally, the endo-complex $\mathbf{1}^{-\mathbf{H +}, \mathbf{R}^{\prime} \mathbf{N H}{ }^{+}} \supset \mathbf{R}^{\prime} \mathbf{N H}_{3}{ }^{+}, \mathbf{P i c}^{-}$ (with $\mathrm{R}^{\prime}=\mathrm{Pr}$ ) was also obtained by the addition of 1 equiv. of $\mathrm{R}^{\prime} \mathrm{NH}_{3}{ }^{+}, \mathrm{Pic}^{-}$and 1 equiv. of its corresponding free amine to a $\mathrm{CDCl}_{3}$ solution of $\mathbf{1}$ (Scheme 1).

These NMR studies emphasize the remarkable ability of calix[6]tris-acid $\mathbf{1}$ for the endocomplexation of small ammonium ions. ${ }^{21}$ Similarly to the calix[6]tris-ammonium receptors 
(Figure 1, left), the crucial rigidification of the calixarene structure clearly takes place thanks to the assembly of a supramolecular cap that closes the narrow rim. Indeed, the exo-binding of at least one ammonium ion (i.e. exo- $\mathrm{R}^{\prime} \mathrm{NH}_{3}{ }^{+}$) is required for the formation of the endocomplexes. Very interestingly, either the carboxylic or the carboxylate groups can efficiently elaborate this cap since it has been evidenced that the calix[6]tris-acid $\mathbf{1}$ can host small ammonium ions whatever its protonation state (Scheme 1). This highlights the versatility of the calix[6]tris-acid $\mathbf{1}$ in the recognition of ammonium ions.

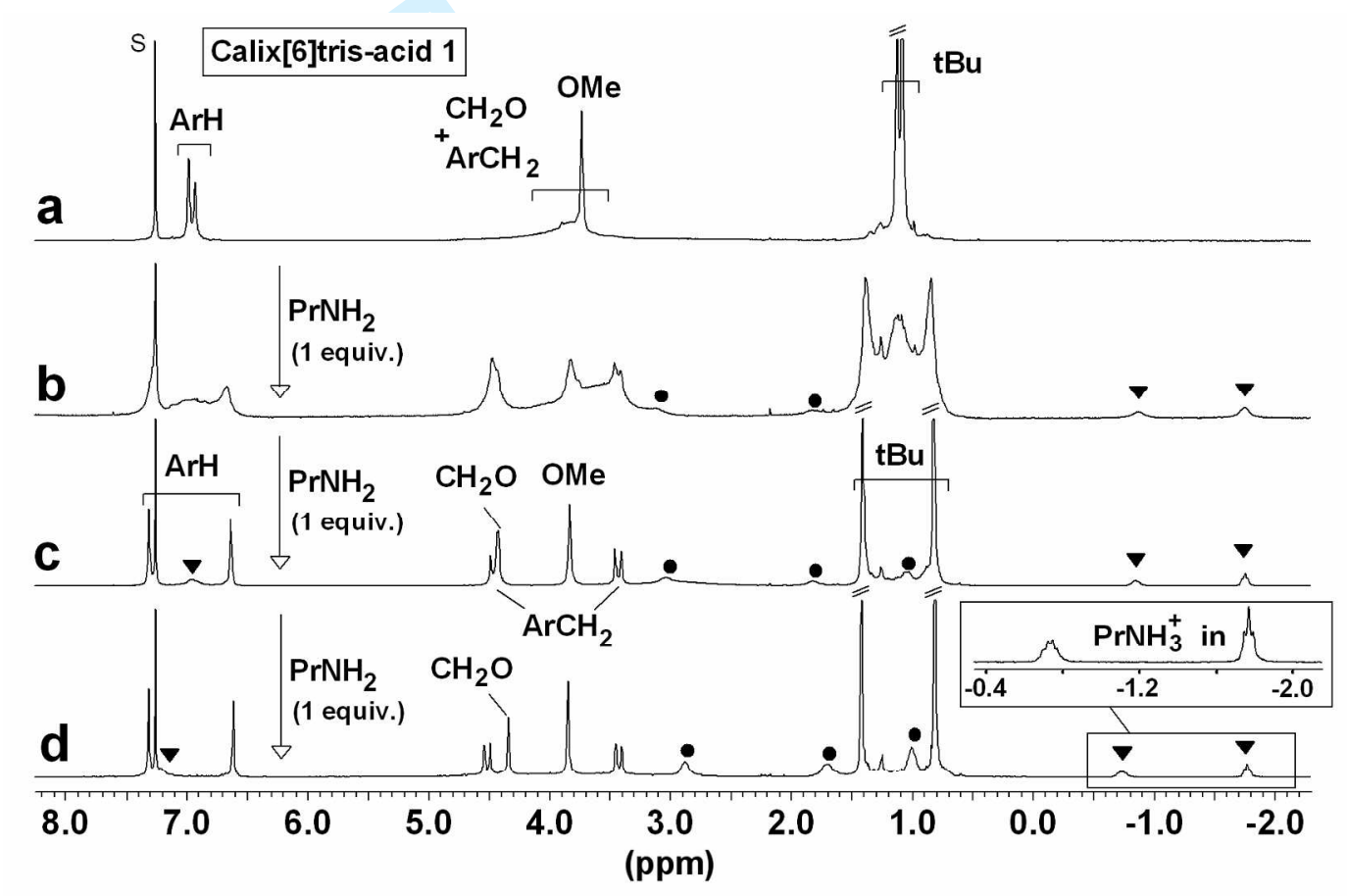

Figure 2. ${ }^{1} \mathrm{H}$ NMR spectra $\left(300 \mathrm{MHz}, \mathrm{CDCl}_{3}\right.$ ) at $294 \mathrm{~K}$ : (a) calix[6]tris-acid 1; (b) Mixture of $\mathbf{1}$ and $\mathbf{1}^{-\mathbf{2 H}+, \mathbf{P r N H}^{+}} \supset \mathbf{P r N H}_{3}{ }^{+}$obtained upon the addition of 1 equiv. $\mathrm{PrNH}_{2}$ to $\mathbf{1}$; (c) $\mathbf{1}^{-}$ ${ }^{2 \mathbf{H}+, \mathrm{PrNH}^{+}}{ }^{+} \mathbf{P r N H}_{3}{ }^{+}$obtained upon the addition of 2 equiv. $\mathrm{PrNH}_{2}$ to $\mathbf{1}$; (d) $\mathbf{1}^{-}$ ${ }^{3 \mathbf{H}+, 2 \mathbf{P r N H} 3+}{ }^{+} \mathbf{P r N H}_{3}{ }^{+}$obtained upon the addition of 3 equiv. $\mathrm{PrNH}_{2}$ to 1. $\bullet$ : exo- $\mathrm{PrNH}_{3}{ }^{+}, \mathbf{\nabla}$ : included $\mathrm{PrNH}_{3}{ }^{+}$. Residual solvent has been labeled "S". 
Scheme 1. The four different ways for the endo-complexation of ammonium ions with calix[6]tris-acid 1 (in $\mathrm{CDCl}_{3}$ ).

\section{Characterization of the endo-complex $\mathrm{I}^{-3 \mathrm{H}+2 \mathrm{Et} \mathrm{NH} 3+} \mathrm{JEtNH}_{3}{ }^{+}$in the solid state.}

Upon slow diffusion of ether, X-ray quality crystals of the endo-complex $\mathbf{1}^{-}$ ${ }^{3 \mathbf{H}+, 2 \mathrm{EtNH} 3+}{ } \mathbf{E t N H}_{3}{ }^{+}$were grown at $4{ }^{\circ} \mathrm{C}$ out of a $\mathrm{CHCl}_{3}$ solution of the calix[6]tris-acid $\mathbf{1}$ and 3 equiv. of $\mathrm{EtNH}_{2}$. The resulting molecular structure displayed in Figure 3 provides a rare example of a calixarene including an ammonium guest deeply in its cavity. The calixarene adopts a flattened cone conformation with the carboxylates arms directed toward the inside of the cavity, the $t \mathrm{Bu}$ groups of the anisol moieties closing the entrance of the cavity at the large rim. The presence of three ethylammonium molecules as well as the short and quasiequivalents $\mathrm{C}-\mathrm{O}$ bond lengths of the $\mathrm{CO}_{2}$ groups $(\mathrm{dC}-\mathrm{O}=1.188$ to $1.266 \AA)$ attest that the three carboxylic groups are deprotonated (Figure 3, top left). One ethylammonium molecule stands in the heart of the cavity and orients its dipolar moment along the $C_{3 \mathrm{v}}$ axis of the calixarene denoting dipole-charge interactions with the tris-anionic binding site. Moreover, 
the three carboxylate groups point specifically toward the $\mathrm{NH}_{3}{ }^{+}$group of the guest at $\mathrm{H}$ bond distances $\left(\mathrm{dO}_{10} \cdots \mathrm{N}_{2}=2.817 \AA, \mathrm{dO}_{2} \cdots \mathrm{N}_{2}=2.781 \AA\right.$ and $\left.\mathrm{dO}_{6} \cdots \mathrm{N}_{2}=2.776 \AA\right)$. Thus, the $C_{3^{-}}$binding geometry displayed by the carboxylates allows a remarkable preorganization for the recognition of the ammonium guest (Figure 3, top right). As previously observed on closely related host-guest adducts, ${ }^{8,13}$ the methyl group of the guest is oriented toward an aromatic ring of the calixarene at a perpendicular distance of $c a$. $3.61 \AA$, attesting a stabilizing $\mathrm{CH}-\pi$ interaction. All these features emphasize a strong complementarity in terms of size, shape and electronic structures between the calixarene host and its ammonium guest. The two other ethylammonium molecules $\left(\right.$ exo- $\mathrm{EtNH}_{3}{ }^{+}$) bridge the three carboxylate groups thanks to ionpaired interactions and to the establishment of four hydrogen bonds $\left(\mathrm{dO}_{10} \cdots \mathrm{N}_{6}=2.730 \AA\right.$, $\mathrm{dO}_{2} \cdots \mathrm{N}_{6}=2.707 \AA, \mathrm{dO}_{7} \cdots \mathrm{N}_{4}=2.729 \AA$ and $\mathrm{dO}_{3} \cdots \mathrm{N}_{4}=2.808 \AA$ ). Hence, as shown in solution through the NMR studies, the role of these exo-EtNH${ }_{3}{ }^{+}$molecules consists in assembling the carboxylate arms in a supramolecular cap which shapes the calixarene structure in the required cone conformation and furthermore provides a well preorganized binding site for ammonium ions. Very interestingly, intermolecular $\mathrm{H}$ bonds are observable in the lattice. They involve the exo-EtNH${ }_{3}{ }^{+}$molecules and the carboxylate groups of two calix[6]arenes which are assembled in a tail-to-tail fashion $\left(\mathrm{dO}_{11} \cdots \mathrm{N}_{4}=2.735 \AA, \mathrm{dO}_{11} \cdots \mathrm{N}_{6}=2.830 \AA\right)$ (Figure 3, bottom). Thus, in the solid state, two calix[6]arene subunits share their exoammonium ions, providing four additional intermolecular $\mathrm{H}$ bonds which further stabilize the supramolecular edifice. This denotes a cooperative process since each of the six ammonium molecules involved in the dimeric self-assembly establishes its maximum of $\mathrm{H}$ bond interactions. $^{22}$ 

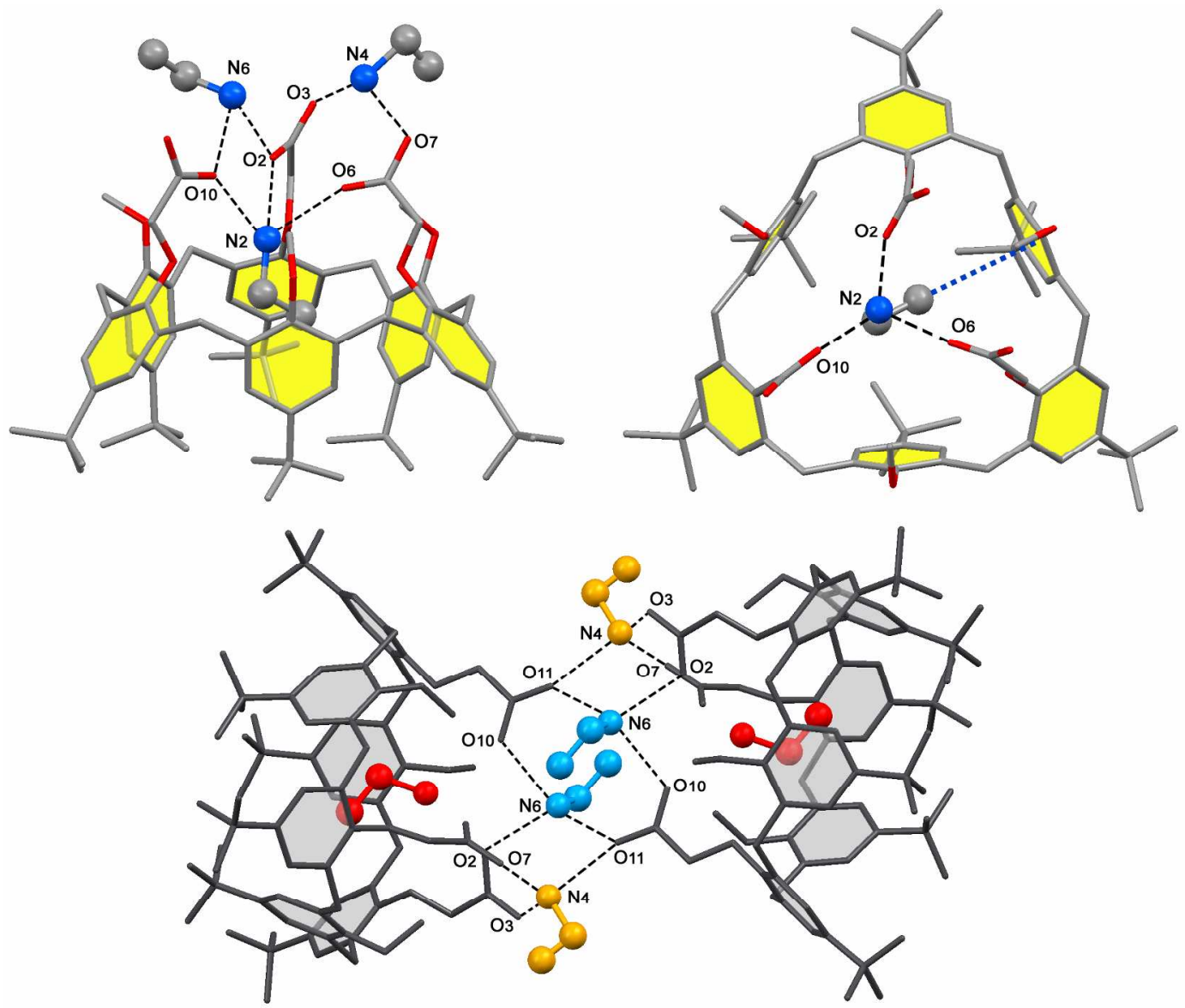

Figure 3. X-ray structure of $\mathbf{1}^{-3 \mathbf{H}+, \mathbf{2 E t N H 3}+} \mathbf{E t N H}_{3}{ }^{+}$displaying the $\mathrm{H}$ bonds (dark dashed lines) between the $\mathrm{NH}_{3}{ }^{+}$and $\mathrm{COO}^{-}$groups and the $\mathrm{CH}-\pi$ interaction (blue dashed line) between the methyl group of the guest and an aromatic ring of the host. Hydrogen atoms and solvents of crystallization were omitted for clarity. The calixarene host and the ammonium ions are depicted respectively in capped stick and ball and stick models. Top left: side view of the monomeric subunit. Top right: top view of the monomeric subunit; exo-ammonium ions were omitted for clarity. Bottom: side view of the dimeric assembly; the molecules have been colorized by symmetry equivalence.

NMR studies of the endo-complexation of various ammonium ions by calix[6]tris-acids 1 and 2.

Similarly to 1, the host-guest behavior of calix[6]tris-acid 2 toward $\mathrm{PrNH}_{3}{ }^{+}$was investigated by ${ }^{1} \mathrm{H}$ NMR spectroscopy in $\mathrm{CDCl}_{3}$ at $294 \mathrm{~K}$. In this case, 3 equiv. of $\mathrm{PrNH}_{2}$ were needed for 
the exclusive formation of an endo-complex. Moreover, no ammonium ion inclusion could be detected after the introduction of an excess of $\mathrm{PrNH}_{3}{ }^{+}, \mathrm{Pic}^{-}$in a $\mathrm{CDCl}_{3}$ solution of $\mathbf{2}$, even at low temperature $(260 \mathrm{~K})$. These results show that, in contrast to $\mathbf{1}$, the calix[6]tris-acid $\mathbf{2}$ has to be totally deprotonated (i.e. $\mathbf{2}^{-3 \mathrm{H}+}$ ) for an efficient endo-complexation of ammonium ions.

Hence, in a second set of NMR experiments, we tested the ability of the hosts $\mathbf{1}^{-\mathbf{3 H +}}$ and $\mathbf{2}^{-}$ ${ }^{3 \mathbf{H}+}$ for the recognition of ammonium ions of various size, shape and structure. In particular, we wanted to study if an inclusion of biologically important ammonium ions was possible inside the hydrophobic cavity of these receptors. The ammonium ions which were successfully endo-complexed are displayed in Scheme 2. In all cases, free and included guests were seen in slow exchange indicating their strong binding by the calixarene host. The observed NMR complexation induced upfield shifts (CIS) ${ }^{23}$ attest to the deep inclusion of the guests in the cavity (for the CIS, see the values displayed in Scheme 2). Thus, host $\mathbf{1}^{\mathbf{- 3 H +}}$ was able to endo-complex a $\beta$-hydroxy ammonium ion [derived from ( \pm )-1-amino-propan-2-ol] ${ }^{24}$ as well as a secondary cyclic ammonium ion (i.e. pyrrolidinium). Upon similar conditions $\left(\mathrm{CDCl}_{3}, 294 \mathrm{~K}\right)$, bulkier ammonium ions derived from trimethylamine, piperidine (PIPNH) and phenethylamine $\left(\mathrm{PEANH}_{2}\right)$ were not detected in the cavity of $\mathbf{1}^{\mathbf{- 3 H +}}$. In these cases, the calixarene structure displayed high-field shifted resonances for the methoxy groups showing that they partially occupied the hydrophobic cavity. However, the endo-complexation of $\mathrm{PEANH}_{2}$ and PIPNH was successfully achieved with host $\mathbf{2}^{-3 \mathrm{H}+}$, thus leading to the corresponding endo-complexes $2^{-3 \mathbf{3 H}+, 2 \mathbf{P E A N H} 3+}{ } \mathbf{P E A N H}_{3}{ }^{+}$and $\mathbf{2}^{-3 \mathrm{H}+, 2 \mathbf{P I P N H} 2+} \mathrm{PPIPNH}_{2}{ }^{+25}{ }^{25}$ This result clearly demonstrates that the removal of the $t$-Bu groups of the anisol moieties is an efficient strategy for the opening of the calixarene cavity and the binding of large guests. Similarly, the corresponding ammonium ions of the bulky tryptamine, 6-methoxytryptamine and of an organosoluble dopamine derivative (i.e. 3,4-dimethoxyphenethylamine) were also endo-complexed by host $2^{-3 \mathrm{H}+}$. Finally, to our delight, the inclusion of biological polyamines 


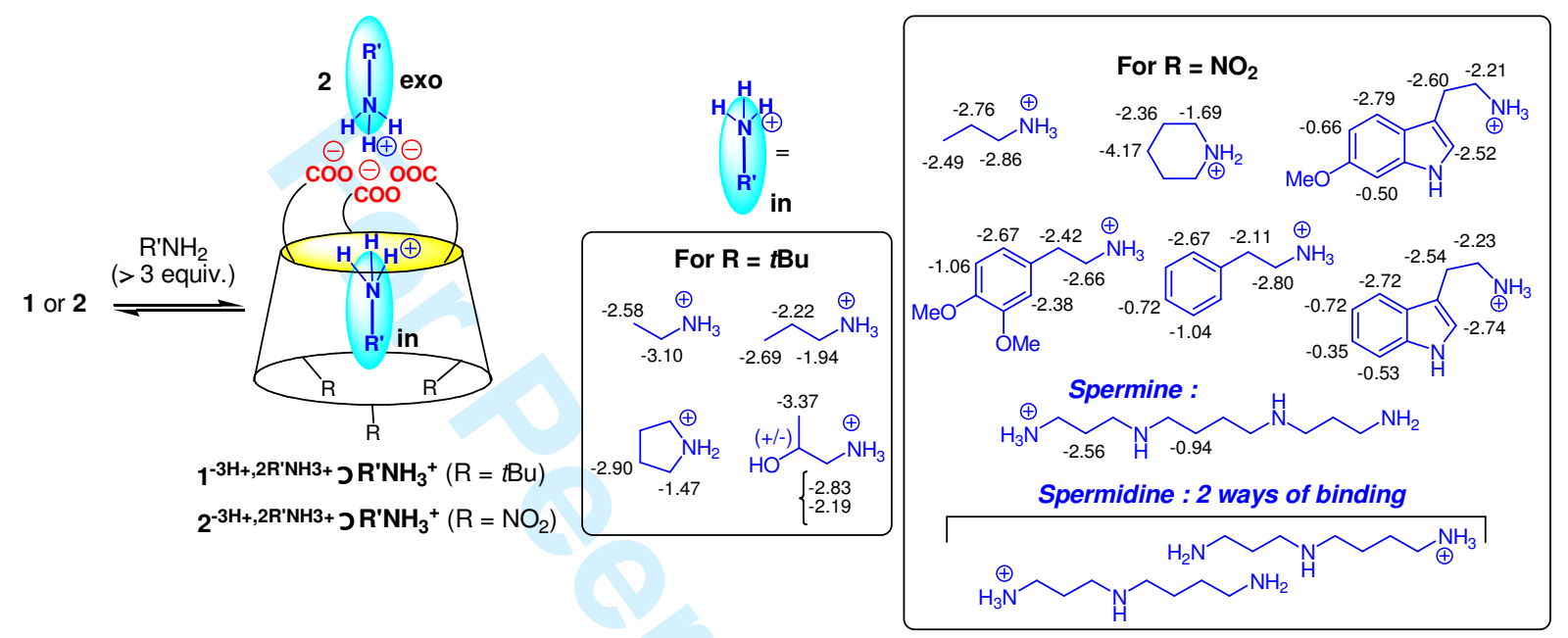

such as spermine and spermidine was also detected inside the cavity of $\mathbf{2}^{-3 \mathbf{H}+}$. In the case of the spermidine, two endo-complexes were observed in a $c a$. 1:1 ratio showing two different ways of binding (Scheme 2).

Scheme 2. Endo-complexation of ammonium ions by receptors $\mathbf{1}^{-3 \mathbf{H}+}, \mathbf{2}^{-3 \mathbf{H}+}$ in $\mathrm{CDCl}_{3}$ and NMR complexation induced upfield shifts (CIS) of various ammonium guests.

The stability of the endo-complexes $\mathbf{1}^{-\mathbf{3 H +}, \mathbf{2 P r N H} 3+} \supset \mathbf{P r N H}_{3}{ }^{+}$and $2^{-3 \mathrm{H}+, 2 \mathbf{P r N H}+}{ }^{+} \mathbf{P r N H}_{3}{ }^{+}$was evaluated by NMR spectroscopy. Their ${ }^{1} \mathrm{H}$ NMR spectra was not affected over a large temperature range (223-330 K). In particular, the in and out guest exchange was still slower than the NMR time scale at high temperature (330 K), confirming a strong association with the hosts. Surprisingly, these host-guest adducts reveal to be remarkably resistant in polar and protic solvents which usually compete for $\mathrm{H}$-bonding. ${ }^{26}$ Indeed, the endo-complexes $\mathbf{1}^{-}$ ${ }^{3 \mathrm{H}+, 2 \mathrm{PrNH}^{+}+} \mathrm{PrNH}_{3}{ }^{+}$and $\mathbf{2}^{-\mathbf{3 H}+, 2 \mathrm{PrNH}^{+}+} \mathrm{PrNHH}_{3}{ }^{+}$possess a well defined and unique NMR signature in pure DMSO-d $\mathrm{d}_{6} \cdot \mathbf{2}^{-\mathbf{3 H +}, \mathbf{2 P r N H}+}{ }_{\supset} \mathbf{P r N H}_{3}{ }^{+}$also survived in pure $\mathrm{CD}_{3} \mathrm{OD}$ and $50 \%$ of the endo-complex was still present in a $c a$. 4:1 DMSO- $\mathrm{D}_{6} / \mathrm{D}_{2} \mathrm{O}$ solution after addition of an excess of $\mathrm{PrNH}_{2}$ ( $c$ a. 30 equiv.). In contrast, the endo-complex $\mathbf{1}^{\mathrm{PrNH}^{+}} \mathrm{\supset PrNH}_{3}{ }^{+}, \mathbf{2 P i c}^{-}$, which 
possesses a cap maintained only through H-bonding, was destroyed by the addition of a small amount of $\mathrm{CD}_{3} \mathrm{OD}(\approx 1 \%)$ into the $\mathrm{CDCl}_{3}$ solution. This last result emphasizes the superiority of the ionic interactions in the stabilization of these host-guest adducts.

\section{Tuning of the ion-paired cap.}

As shown above, the endo-complexation of an ammonium guest in the cavity of the calix[6]tris-acids $\mathbf{1}$ and $\mathbf{2}$ requires the exo-complexation of at least one bridging exoammonium ion for the assembly of the supramolecular cap. Thus, the next degree of sophistication consisted in the elaboration of receptors displaying a supramolecular cap constructed with an exo-ammonium ion which differs from the included one. Indeed, with such receptors, the design of highly responsive sensors for ammonium ions can be envisaged. For this, our strategy was based on the formation of the cap thanks to a bulky ammonium ion (i.e. $t \mathrm{BuNH}_{3}{ }^{+}$) unable to be included in the cavity. Hence, the tris- $t \mathrm{BuNH}_{3}{ }^{+}$salts of $\mathbf{1}$ and $\mathbf{2}$, namely $\mathbf{1}^{-\mathbf{3 H +}, \mathbf{3 t B u N H} 3+}$ and $\mathbf{2}^{-\mathbf{3 H +}, \mathbf{3 t B u N H 3 +}}$ were isolated in $82 \%$ and $98 \%$ yields respectively (Scheme 3). Their ${ }^{1} \mathrm{H}$ NMR spectra in $\mathrm{CDCl}_{3}$ reflected $C_{3 \mathrm{v}}$-symmetrical species rigidified in a major cone conformation and no inclusion of $t \mathrm{BuNH}_{3}^{+}$was observed (Figure $4 \mathrm{a}$, for $\mathbf{2}^{-}$ $3 \mathrm{H}+, 3 \mathrm{tBuNH}+)^{27}$

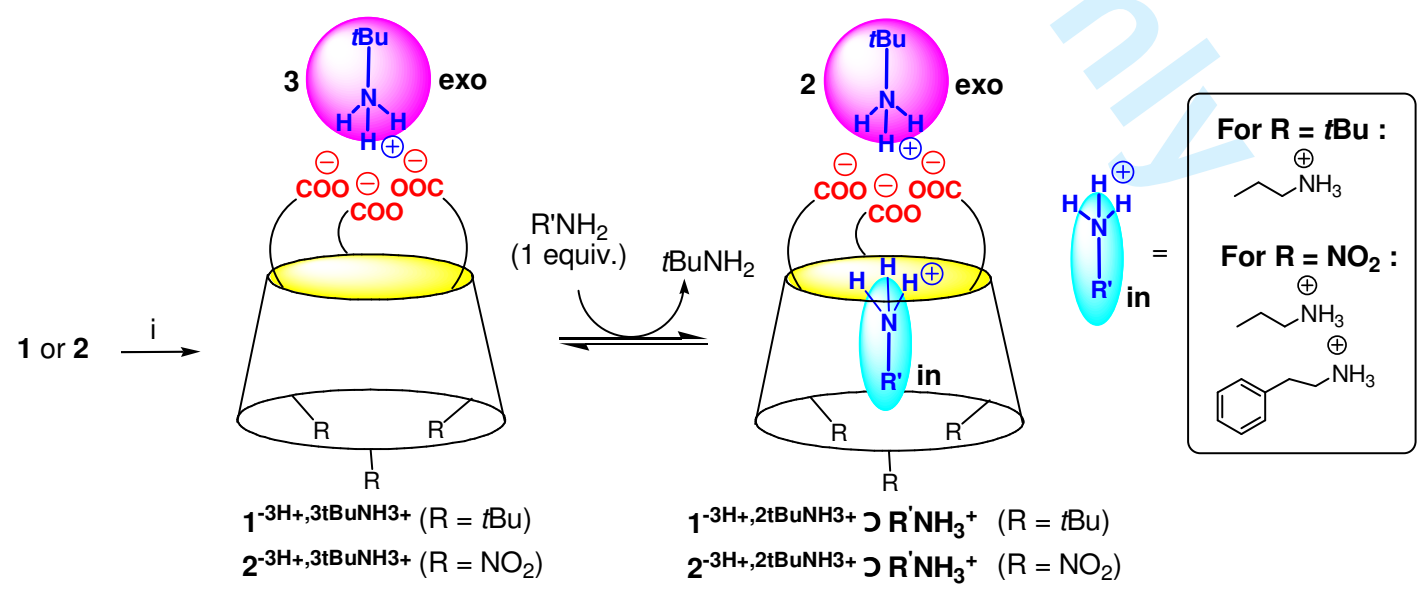


Scheme 3. Preparation and host-guest properties (in $\mathrm{CDCl}_{3}$ ) of the receptors $\mathbf{1}^{\mathbf{- 3 H +}, \mathbf{3 t B u N H 3 +}}$ and $\mathbf{2}^{-\mathbf{3 H +}+\mathbf{3 t B u N H} 3+}$. i) $t \mathrm{BuNH}_{2}$ (> 3 equiv.), $\mathrm{CHCl}_{3}, 82 \%$ and $98 \%$ respectively.

The host-guest behavior of both salts was investigated by ${ }^{1} \mathrm{H}$ NMR spectroscopy. The addition of 1 equiv. of $\mathrm{PrNH}_{2}$ into a $\mathrm{CDCl}_{3}$ solution of either $\mathbf{1}^{-3 \mathrm{H}+, 3 \mathrm{tBuNH} 3+}$ or $\mathbf{2}^{-\mathbf{3 H}+, \mathbf{3 t B u N H} 3+}$ led to the corresponding endo-complexes $\mathbf{1}^{-3 \mathrm{H}+, 2 \mathrm{tBuNH} 3+} \supset \mathrm{PrNH}_{3}{ }^{+}$and $2^{-3 \mathrm{H}+, \mathbf{2 t B u N H} 3+} \supset \mathbf{P r N H}_{3}{ }^{+}$as the only observable species. Thus, this very selective recognition process was associated to the release of one equivalent of $t \mathrm{BuNH}_{2}$. The driving force for the counter-ion exchange and the inclusion of the ammonium ion should stand in part in the establishment of additional $\mathrm{CH}$ $\pi$ interactions in the host-guest adduct. It is noteworthy that upon addition of less than one equivalent of the $\mathrm{PrNH}_{2}$, no exo- $\mathrm{PrNH}_{3}{ }^{+}$could be detected. Hence, the association constant of $\mathbf{P r N H}_{3}{ }^{+}$toward $\mathbf{1}^{-3 \mathbf{H}+, 2 \mathrm{tBuNH} 3+}$ was estimated to be at least $1.2 \times 10^{5} \mathrm{M}^{-1}$. Similarly, only 1 equiv. of the bulky phenethylamine was necessary for the exclusive formation of the endocomplex $2^{-3 \mathbf{H}+, 2 \mathrm{tBuNH}+}{ }^{+} \mathbf{P E A N H}_{3}^{+}$(Figure $\left.4 \mathrm{~b}\right)$.

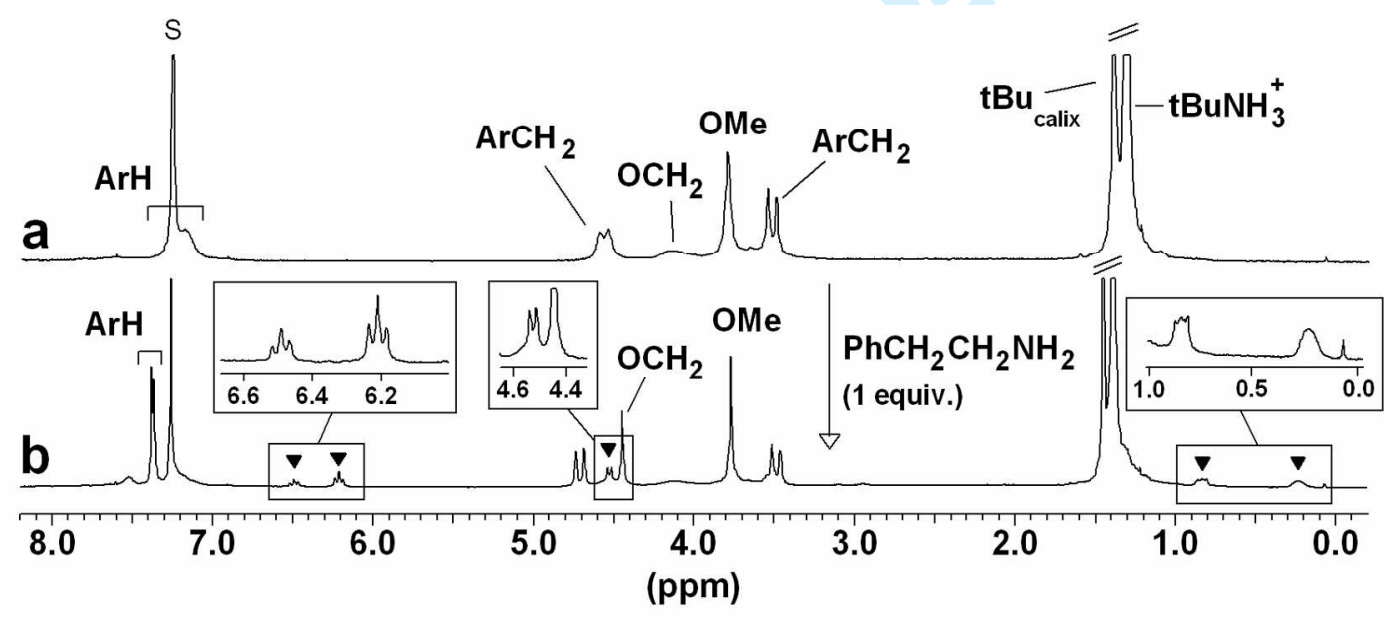

Figure 4. ${ }^{1} \mathrm{H}$ NMR spectra $\left(300 \mathrm{MHz}, \mathrm{CDCl}_{3}\right)$ at $294 \mathrm{~K}$. (a) $\mathbf{2}^{\mathbf{- 3 H +}, \mathbf{3 t B u N H 3 +}}$; (b) $\mathbf{2}^{-}$ ${ }^{3 \mathbf{H}+, 2 \mathrm{tBuNH} 3}{ }^{+} \mathrm{PEANH}_{3}{ }^{+}$obtained upon the addition of 1 equiv. of $\mathrm{PEANH}_{2}$ to $2^{-3 \mathbf{H}+, 3 \mathrm{tBuNH} 3+}$. $\boldsymbol{\nabla}$ : included $\mathrm{PEANH}_{3}{ }^{+}$. Residual solvent has been labeled "S". 


\section{Conclusion}

In conclusion, we have shown that calix[6]tris-acids $\mathbf{1}$ and $\mathbf{2}$ behave as remarkable hosts for ammonium ions under experimental conditions for which the calix[6]tris-ester and tris-amide derivatives are inefficient. In particular, the inclusion of large biological ammonium ions was achieved with the calix[6]tris-acid 2 which possesses an open cavity. As evidenced through NMR studies and a X-ray structure, the preorganization of the molecular receptors in a welldefined rigid cone conformation takes place thanks to the self-assembly of a supramolecular cap that closes the narrow rim of the calixarene and thus provides a suitable interaction site for ammonium ions. This required cap is formed through the association of the terminal carboxylate or carboxylic groups and exo-ammonium ions via hydrogen bonding and ionpaired interactions. The X-ray structure of an host-guest complex showed, on one hand, a remarkable $C_{3}$-complementarity between the well-organized binding carboxylates of the host and the ammonium guest and, on the other hand, a cooperative tail-to-tail dimeric selfassembly of two calixarenes subunits. The host-guest adducts possessing an ion-paired cap revealed to be highly stable in polar and protic solvents. Finally, the assembly of the cap was also performed with a bulky ammonium ion unable to enter into the cavity. In this case, it led to molecular receptors able to respond, through a very selective process, to only one equivalent of an ammonium ion present in solution. All this work highly contributes to the rationalization of ammonium ions complexation by macrocyclic receptors in organic media. In addition, it shows the efficiency of the calix[6]arene platform, along with ionic interactions, for the recognition of ammonium ions in protic media and thus opens interesting perspectives for the elaboration of sensors for bioactive ammonium ions in aqueous media as well as self-assembled nano-size objects. 


\section{Experimental Section}

General Experimental Methods: $\mathrm{CHCl}_{3}$ was distilled over $\mathrm{P}_{2} \mathrm{O}_{5}$ under argon. All reactions were performed under an inert atmosphere. ${ }^{1} \mathrm{H}$ and ${ }^{13} \mathrm{C}$ NMR spectra were recorded at 300 and $75 \mathrm{MHz}$ respectively. Chemical shifts are expressed in ppm. $J$ values are given in $\mathrm{Hz}$. Traces of residual solvent were used as internal standard. IR spectra were recorded on a Perkin-Elmer IRFT Paragon 1000 apparatus. Elemental analyses were performed at the Laboratoire de Microanalyse Organique (IRCOF, Mont Saint Aignan, France). Calix[6]trisacids $\mathbf{1}$ and $\mathbf{2}$ were prepared according to the literature. ${ }^{15,16}$

$\mathbf{1}^{-\mathbf{3 H +}+3 \mathrm{tBuNH}+}$. Calix[6]tris-acid $\mathbf{1}(30 \mathrm{mg}, 0.025 \mathrm{mmol})$ was dissolved in $\mathrm{CHCl}_{3}(0.4 \mathrm{~mL})$ and $t \mathrm{BuNH}_{2}(16 \mu \mathrm{L}, 0.15 \mathrm{mmol})$ was added. After $5 \mathrm{~min}$ of stirring at room temperature, $\mathrm{Et}_{2} \mathrm{O}$ $(1 \mathrm{~mL})$ was added and the resulting precipitate was isolated by centrifugation, washed with $\mathrm{Et}_{2} \mathrm{O}(2 \times 0.2 \mathrm{~mL})$ and then dried over vacuum to yield $\mathbf{1}^{-\mathbf{3 H +}, 3 \mathrm{tBuNH}+}(29 \mathrm{mg}, 82 \%)$ as a white solid. mp: $270{ }^{\circ} \mathrm{C}$; (Found: C, 70.1; H, 9.3; N, 2.6. Calc. for $\mathrm{C}_{75} \mathrm{H}_{93} \mathrm{O}_{12}, 3 \mathrm{C}_{4} \mathrm{H}_{12} \mathrm{~N}, 4.5 \mathrm{H}_{2} \mathrm{O}: \mathrm{C}$, $70.1 ; \mathrm{H}, 9.3 ; \mathrm{N}, 2.8 \%) ; v_{\max }(\mathrm{KBr}) / \mathrm{cm}^{-1} 3680$ to $3120,1694,1595,1482,1415 ; \delta_{\mathrm{H}}(300 \mathrm{MHz}$; $\left.\mathrm{CDCl}_{3}\right) 0.85\left(27 \mathrm{H}, \mathrm{s}, t \mathrm{Bu}_{\text {calix }}\right), 1.30\left(27 \mathrm{H}, \mathrm{s}, t \mathrm{Bu}_{\text {calix }}\right), 1.40\left(27 \mathrm{H}, \mathrm{s}, t \mathrm{Bu}_{\mathrm{NH} 3+}\right), 2.41(9 \mathrm{H}$, br s, OMe), $3.42\left(6 \mathrm{H}, \mathrm{d}, J\right.$ 15, $\left.\mathrm{ArCH}_{e q}\right), 4.45\left(6 \mathrm{H}, \mathrm{s}, \mathrm{OCH}_{2}\right), 4.50\left(6 \mathrm{H}, \mathrm{d}, J 16, \mathrm{ArCH}_{a x}\right), 6.91(6$ $\mathrm{H}, \mathrm{s}, \mathrm{ArH}), 7.18(6 \mathrm{H}, \mathrm{s}, \mathrm{ArH}) . \delta_{\mathrm{C}}\left(75 \mathrm{MHz} ; \mathrm{CDCl}_{3}\right) 28.1,29.9,31.1,31.5,34.0,34.2,51.5$, $60.6,124.2,127.9,132.7,133.4,146.1,146.3,151.2,153.7,174.3$.

$\mathbf{2}^{-3 \mathrm{H}+, 3 \mathrm{BBuNH} 3+}$. Calix[6]tris-acid $2(30 \mathrm{mg}, 0.026 \mathrm{mmol})$ was dissolved in $\mathrm{CHCl}_{3}(1 \mathrm{~mL})$ and $t \mathrm{BuNH}_{2}(55 \mu \mathrm{L}, 0.52 \mathrm{mmol})$ was added. After $30 \mathrm{~min}$ of stirring at room temperature, the solution was concentrated to dryness under reduced pressure. The resulting solid was washed with $\mathrm{Et}_{2} \mathrm{O}(2 \times 0.2 \mathrm{~mL})$ and then dried over vacuum to yield $\mathbf{2}^{-3 \mathbf{H}+, 3 \mathrm{tBuNH}+}(35 \mathrm{mg}, 98 \%)$ as a beige solid. mp: $160{ }^{\circ} \mathrm{C}$ (decomp.); (Found: C, 58.0; H, 6.8; N, 5.7. Calc. for $\left.\mathrm{C}_{63} \mathrm{H}_{66} \mathrm{~N}_{3} \mathrm{O}_{18}, 3 \mathrm{C}_{4} \mathrm{H}_{12} \mathrm{~N}, \mathrm{CHCl}_{3}, 4 \mathrm{H}_{2} \mathrm{O}: \mathrm{C}, 58.25 ; \mathrm{H}, 7.1 ; \mathrm{N}, 5.4 \%\right) ; v_{\max }(\mathrm{KBr}) / \mathrm{cm}^{-1} 3700$ to 
3160, 1700 to $1550,1523,1480,1405,1344 ; \delta_{\mathrm{H}}\left(300 \mathrm{MHz} ; \mathrm{CDCl}_{3}\right) 1.32\left(27 \mathrm{H}, \mathrm{s}, t \mathrm{Bu}_{\mathrm{NH} 3+}\right)$, $1.39\left(27 \mathrm{H}, \mathrm{s}, t \mathrm{Bu}_{\text {calix }}\right), 3.52\left(6 \mathrm{H}, \mathrm{d}, J 16, \mathrm{ArCH}_{e q}\right), 3.80(9 \mathrm{H}, \mathrm{s}, \mathrm{OMe}), 4.16(6 \mathrm{H}$, br s, $\left.\mathrm{OCH}_{2}\right), 4.57$ (6 H, d, J 15, $\left.\mathrm{ArCH}_{a x}\right), 7.18(12 \mathrm{H}, \mathrm{s}, \mathrm{ArH})$.

X-ray structure determination of complex $1^{-3 \mathrm{H}+, 2 \mathrm{EtNH} 3+} \mathrm{EtNH}_{3}{ }^{+}$. Diffraction data were measured on a Bruker-Nonius KappaCCD diffractometer. ${ }^{28}$ Crystals were unstable upon standing to air and were rapidly fished out from their mother liquor using a cryoloop and frozen under a cold nitrogen stream. Data sets consist of 180 frames, 1 degree-rotation each (exposure time: $60 \mathrm{~s}$ per frame). Frames were processed using the DENZO/HKL package. ${ }^{29}$ The structures were solved by direct methods and refined using SHELXL. ${ }^{30}$ Refinement details: the complex co-crystallized with highly disordered solvent molecules which were modelled as two ether molecules with occupancy equal to 0.5 and 0.7 respectively and one water molecule with occupancy 0.3 . Two tert-butyl groups were also splitted on two sites because of static disorder with occupancy equal to 0.3 and 0.7 respectively for the two sites of one tert-butyl and occupancy equal to 0.4 and 0.6 respectively for the two sites of the second tert-butyl. All hydrogen atoms were introduced in the calculation with their isotropic thermal factor riding on that of the bonded atom but not refined. Those of the disordered tert-butyl groups were omitted from the calculation as well as those of the disordered ether and water molecules. Crystal data: $\mathrm{C}_{86.8} \mathrm{H}_{130.6} \mathrm{Cl}_{3} \mathrm{O}_{13.5} \mathrm{~N}_{3}, \mathrm{M}_{\mathrm{w}}=1538.49$, monoclinic, colorless crystal $\left(0.4 \times 0.3 \times 0.2 \mathrm{~mm}^{3}\right), \mathrm{a}=19.8304(2) \AA, \mathrm{b}=18.5246(2) \AA, \mathrm{c}=30.4264(3) \AA, \beta=$ 123.3431(5) ${ }^{\circ}, \mathrm{V}=9337.32(17) \AA^{3}$, space group $\mathrm{P} 21 / \mathrm{c}, \mathrm{Z}=4, \rho=1.094 \mathrm{gcm}^{-3}, \mu(\mathrm{MoK} \alpha)=$ $1.55 \mathrm{~cm}^{-1}, 70626$ reflections measured at $223 \mathrm{~K}$ in the $0.8-28.56^{\circ} \theta$ range, 23109 unique, 1039 parameters refined on $\mathrm{F}^{2}$ to final indices $\mathrm{R}\left[12181\right.$ refl. : $\left.\mathrm{F}^{2}>4 \sigma \mathrm{F}^{2}\right]=0.1362$, wR[23109 refl.] $=0.4066\left[\mathrm{w}=1 /\left[\sigma^{2}\left(\mathrm{Fo}^{2}\right)+(0.1777 \mathrm{P})^{2}+21.7766 \mathrm{P}\right]\right.$ where $\left.\mathrm{P}=\left(\mathrm{Fo}^{2}+2 \mathrm{Fc}^{2}\right) / 3\right]$. The last residual Fourier positive and negative peaks were equal to 1.115 and -0.605 respectively.

\section{Supplementary Material}

URL: http:/mc.manuscriptcentral.com/tandf/gsch Email: suprachem@mail.cm.utexas.edu 16 
The CIF file for the X-ray structure of $\mathbf{1}^{-\mathbf{3 H +}, \mathbf{2 E t N H}+}{ }^{+} \mathbf{E t N H}_{\mathbf{3}}{ }^{+}$has been deposited at the CCDC with entry number CCDC 299787. NOESY spectrum of $\mathbf{1}^{-3 \mathbf{H}+, 2 \mathbf{P r N H}+}{ }^{+} \mathbf{P r N H}_{\mathbf{3}}{ }^{+},{ }^{1} \mathrm{H}$ NMR spectra of $\mathbf{1}^{-3 \mathbf{H}+, 3 \mathrm{BBuNH}+}\left(\mathrm{CDCl}_{3}, 294 \mathrm{~K}\right), \mathbf{1}^{\mathbf{- 3 H + , 2 t B u N H 3 +}} \mathbf{P r N H}_{\mathbf{3}}^{+}\left(\mathrm{CDCl}_{3}, 294 \mathrm{~K}\right), \mathbf{1}^{-}$

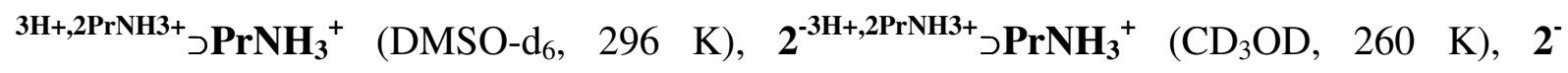

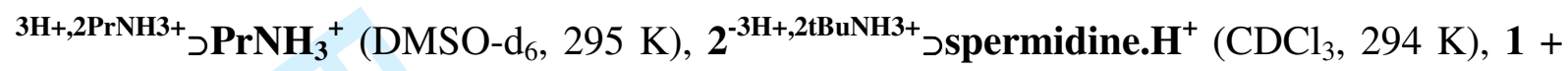
PIPNH $\left(\mathrm{CDCl}_{3}, 260 \mathrm{~K}\right), \mathbf{2}^{-\mathbf{3 H + , 2 P I P N H 2 +}} \supset \mathbf{P I P N H}_{2}{ }^{+}\left(\mathrm{CDCl}_{3}, 260 \mathrm{~K}\right)$ and the procedure for the determination of the association constant of $\mathrm{PrNH}_{3}{ }^{+}$toward $\mathbf{1}^{-3 \mathbf{H}+, \mathbf{2 t B u N H} 3+}$.

Acknowledgments. We thank Pr. Olivia Reinaud for helpful discussions. Part of this work was supported by the French Ministry of Research and New Technologies.

1 For a review on synthetic receptors, see: Hartley, J. H.; James, T. D.; Ward, C. J. J. Chem. Soc., Perkin Trans 1 2000, 3155.

2 For leading examples of molecular recognition of bioactive ammonium ions, see: Takeshita, M.; Shinkai, S. Chem. Lett. 1994, 1349. Magrans, J. O.; Ortiz, A. R.; Molins, M. A.; Lebouille, P. H. P.; Sanchez-Quesada, J.; Prados, P.; Pons, M.; Gago, F.; de Mendoza, J. Angew. Chem. Int. Ed. 1996, 35, 1712. Buschmann, H.-J.; Mutihac, L.; Jansen, K. J. Incl. Phenom. Macrocycl. Chem. 2001, 39, 1. Biros, S. M.; Ullrich E. C.; Hof, F.; Trembleau, L.; Rebek, J. J. J. Am. Chem. Soc. 2004, 126, 2870. Kim, J.; Raman, B.; Ahn, K. H. J. Org. Chem. 2006, 71, 38.

3 Gutsche, C. D. Calixarenes Revisited, Monographs in Supramolecular Chemistry; Stoddart, J. F., Ed.; The Royal Society of Chemistry: Cambridge, U.K., 1998. For a review on calix[6]arenes, see: Lüning, U.; Löffler, F.; Eggert, J. In Calixarenes 2001; 
Asfari, Z., Böhmer, V., Harrowfield, J., Vicens, J., Eds.; Kluwer Academic Publishers: Norwell, MA, 2001; pp 71-88.

4 Dalla Cort, A.; Madolini, L. In Calixarenes in Action; Mandolini, L., Ungaro, R., Eds.; Imperial College Press: London, 2000; pp 85-110. Abraham, W. J. Incl. Phenom. Macrocycl. Chem. 2002, 43, 159. Ludwig, R. Microchim. Acta 2005, 152, 1.

5 Ikeda, A.; Shinkai, S. Chem. Rev. 1997, 97, 1713.

6 Odashima, K.; Yagi, K.; Tohda, K.; Umezawa, Y. Anal. Chem. 1993, 65, 1074. Han, S.Y.; Kang, M.-H.; Jung, Y.; Chang, S.-K. J. Chem. Soc. Perkin Trans 2 1994, 835. Grady, T.; Harris, S. J.; Smyth, M. R.; Diamond, D.; Hailey, P. Anal. Chem. 1996, 68, 3775. Odashima, K.; Yagi, K.; Tohda, K.; Umezawa, Y. Bioorg. Med. Chem. Lett. 1999, 9, 2375.

7 Casnati, A.; Jacopozzi, P.; Pochini, A.; Ugozzoli, F.; Cacciapaglia, R.; Mandolini, L.; Ungaro, R. Tetrahedron 1995, 51, 591. Chen, Y.; Li, J.; Zhong, Z.; Lu, X. Tetrahedron 1998, 54, 15183. Li, J.; Chen, Y.; Lu, X. Tetrahedron 1999, 55, 10365. Chen, Y.; Yang, F. Chem. Lett. 2000, 484. Chen, Y.; Yang, F.; Lu, X. Tetrahedron Lett. 2000, 41, 1571.

8 Darbost, U.; Giorgi, M.; Reinaud O.; Jabin, I. J. Org. Chem. 2004, 69, 4879. Zeng, X.; Hucher, N.; Reinaud, O.; Jabin, I. J. Org. Chem. 2004, 69, 6886. Darbost, U.; Rager, M.N.; Petit, S.; Jabin, I.; Reinaud, O. J. Am. Chem. Soc. 2005, 127, 8517.

9 See also for leading references on the complexation of ammonium ions by calix[5]arenes: Garozzo, D.; Gattuso, G.; Kohnke, F. H.; Malvagna, P.; Notti, A.; Occhipinti, S.; Pappalardo, S.; Parisi, M. F.; Pisagatti, I. Tetrahedron Lett. 2002, 43, 7663. De Salvo, G.; Gattuso, G.; Notti, A.; Parisi, M. F.; Pappalardo, S. J. Org. Chem. 2002, 67, 684. Garozzo, D.; Gattuso, G.; Notti, A.; Pappalardo, A.; Pappalardo, S.; Parisi, M. F.; Perez, M.; Pisagatti, I. Angew. Chem. Int. Ed. 2005, 44, 2. 
10 (a) Castro, R.; Godinez, L. A.; Criss, C. M.; Kaifer, A. E. J. Org. Chem. 1997, 62, 4928.

(b) Douteau-Guevel, N.; Coleman, A. W.; Morel, J.-P.; Morel-Desrosiers, N. J. Chem. Soc., Perkin Trans 2 1999, 629. (c) Kalchenko, O. I.; Da Silva, E.; Coleman, A. W. J. Incl. Phenom. Macrocycl. Chem. 2002, 43, 305.

11 See also for the recognition of ammonium ions by water soluble calix[4]arenes bearing carboxylate groups: Arena, G.; Contino, A.; Gulino, F. G.; Magri, A.; Sansone, F.; Sciotto, D.; Ungaro, R. Tetrahedron Lett. 1999, 40, 1597. Sansone, F.; Barboso, S.; Casnati, A.; Sciotto, D.; Ungaro, R. Tetrahedron Lett. 1999, 40, 4741. Arena, G.; Casnati, A.; Contino, A.; Lombardo, G. G.; Sciotto, D.; Ungaro, R. Chem. Eur. J. 1999, 5, 738. Shimojo, K.; Oshima, T.; Goto, M. Anal. Chim. Acta 2004, 521, 163. Oshima, T.; Inoue, K.; Uezu, K.; Goto, M. Anal. Chim. Acta 2004, 521, 137.

Giorgi, M.; Hucher, N.; Jabin, I.; Reinaud, O. Supramol. Chem. 2005, 17, 243.

14 The efficiency of an electrostatic contribution for the complexation of ammonium ions has been already highlighted: Ref. 10a. Park, S. J.; Hong, J.-I. Tetrahedron Lett. 2000, 41, 8311.

15 For the preparation of 1, see: Castani, A.; Minari, P.; Pochini, A.; Ungaro, R. J. Chem. Soc., Chem. Commun. 1991, 1413.

16 For the preparation of 2, see: Redon, S.; Li, Y.; Reinaud, O. J. Org. Chem. 2003, 68, 7004.

17 Resonances at $\delta_{\mathrm{CH} 2 \mathrm{~N}}=3.22$ and $3.03 \mathrm{ppm}$ (for $\mathrm{R}^{\prime}=$ Et and Pr respectively) clearly indicate the presence of one equivalent of exo- $\mathrm{R}^{\prime} \mathrm{NH}_{3}{ }^{+}$.

18 Since the in and out exchange of the ammonium ion is slower than the NMR time scale at $294 \mathrm{~K}$, the host-guest complex should possess a high $\mathrm{K}_{\text {ass }}$ value. 
19 Similarly, the $\mathrm{NH}_{3}{ }^{+}$signal of the included guests was down-field shifted. This is in good agreement with an increasing acidity of the ammonium group of the guests upon a total deprotonation of the hosts.

20 In the case of the propylammonium ion, a NOESY experiment confirmed that the highfield peaks belong to a guest $\mathrm{PrNH}_{3}{ }^{+}$and allowed us to attribute all the resonances of the guest (See the Supporting Information).

21 It is noteworthy that, at low temperature, no endo-complexation of small neutral polar molecules (i.e. EtOH, DMF or imidazolidin-2-one) was observed with $\mathbf{1}$ or $\mathbf{1}^{-3 \mathbf{H}+}$ (formed by addition of 3 equiv. of the bulky $t \mathrm{BuNH}_{2}$ ), showing that these hosts include ammonium guests specifically.

22 An additional hydrogen bond involving a carboxylate group and a molecule of $\mathrm{CHCl}_{3}$ is observed in the X-ray structure. Hence, the stabilization of the dimeric self-assembly takes place through a network of 20 hydrogen bonds.

23 The CIS values were determined after addition of an excess of the free amine $\mathrm{R}^{\prime} \mathrm{NH}_{2}$ into a $\mathrm{CDCl}_{3}$ solution of the calixarene host (i.e. 1 or 2$)$. CIS were defined as $\Delta \delta=\delta($ complexed ammonium ion $)-\delta($ free amine $)$

24 It is noteworthy that the chirality of the racemic guest is not sensed by the calixarene core, since the host-guest adduct displays a $C_{3 \mathrm{v}}$ symmetrical NMR pattern.

25 The NMR pattern of the calixarene core of $\mathbf{2}^{-3 \mathbf{H}+, 2 \mathbf{P I P N H} 2+} \supset \mathbf{P I P N H}_{2}{ }^{+}$reveals to be dissymmetric at $294 \mathrm{~K}$ (see the Supporting Information) but reflects a pseudo- $C_{3 \mathrm{v}}$ symmetry at $330 \mathrm{~K}$. It may be rationalized by a slow exchange (compared to the NMR time scale) of this bulky secondary ammonium ion between the three binding carboxylates. 
The NMR studies of their stability were conducted in DMSO- $\mathrm{d}_{6}$ at $294 \mathrm{~K}$ after addition of a slight excess of $\mathrm{PrNH}_{2}$ (5 equiv.) to $\mathbf{1}$ and $\mathbf{2}$ and in $\mathrm{CD}_{3} \mathrm{OD}$ at $260 \mathrm{~K}$ after addition of an excess of $\mathrm{PrNH}_{2}$ (ca. 20 equiv.) to $\mathbf{1}$ and $\mathbf{2}$.

27 The ${ }^{1} \mathrm{H}$ NMR spectra of $\mathbf{1}^{-\mathbf{3 H}+, 3 \mathrm{BBuNH} 3+}$ and $\mathbf{2}^{-\mathbf{3 H +}, \mathbf{3 t B u N H} 3+}$, recorded upon similar conditions $\left(\mathrm{CDCl}_{3}, 294 \mathrm{~K}, 3.5 \mathrm{mM}\right)$, show that these compounds possess opposite flattened cone conformation. Indeed, in contrast to $\mathbf{2}^{-3 \mathbf{H}+, 3 \mathrm{tBuNH} 3+}$ (Figure 4a), the methoxy groups of $\mathbf{1}^{-}$ $3 \mathrm{H}+, \mathbf{3 t B u N H} 3+$ are directed toward the inside of the cavity.

28 Bruker-Nonius (1998). Kappa CCD Reference Manual. Nonius B.V., P.O. Box 811, 2600 Av, Delft, The Netherlands.

29 Otwinowsky, Z.; Minor, W. Methods in Enzymol. 1997, 276, 307.

30 Sheldrick, G.M. (1997). SHELXL97. Program for the refinement of crystal structures. Univ. of Gottingen, Germany 


\section{Supporting Information}

Calix[6]arene Tris-carboxylic Acid Derivatives: X-ray and NMR Characterization of their Remarkable Host-guest Properties Toward Ammonium Ions

Stéphane Le Gac, ${ }^{a}$ Michel Giorgi ${ }^{b}$ and Ivan Jabin ${ }^{a} *$

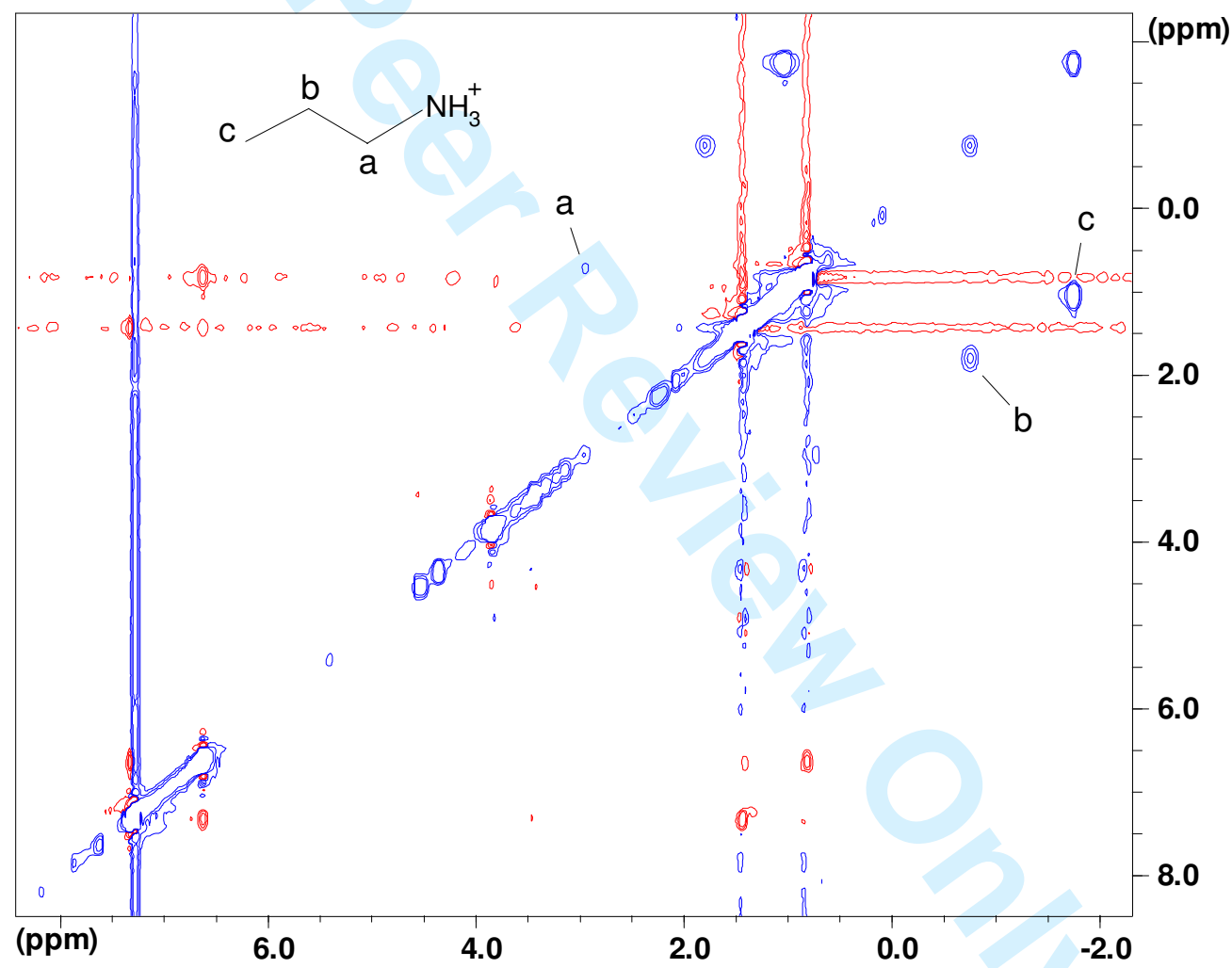

Fig. S1. NOESY $\left(\mathrm{CDCl}_{3}, 294 \mathrm{~K}\right)$ spectrum of $\mathbf{1}^{-\mathbf{3 H +}, \mathbf{2 P r N H} 3+}{ }^{2} \mathbf{P r N H}_{3}{ }^{+}$. 


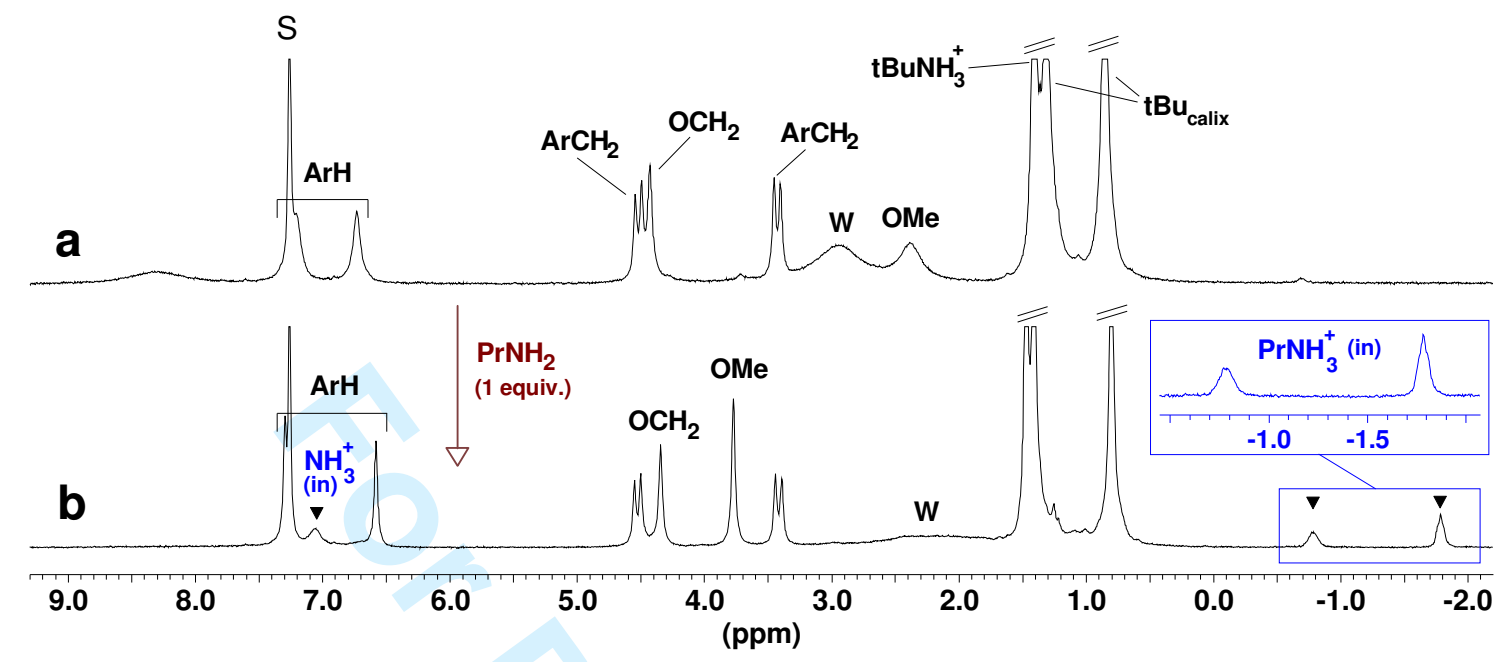

Fig. S2. ${ }^{1} \mathrm{H}$ NMR spectra $\left(300 \mathrm{MHz}, \mathrm{CDCl}_{3}\right)$ at $294 \mathrm{~K}:$ (a) $\mathbf{1}^{-3 \mathrm{H}+, \mathbf{3 t B u N H} 3+}$; (b) $\mathbf{1}^{-}$ ${ }_{3 \mathbf{H}+, 2 \mathrm{tBuNH} 3+}{ }^{3} \mathbf{P r N H}_{3}{ }^{+}$obtained upon the addition of one equiv. of $\mathrm{PrNH}_{2}$ to $\mathbf{1}^{-3 \mathrm{H}+, \mathbf{3 t B u N H} 3+}$. $\mathbf{\nabla}$ : included $\mathrm{PrNH}_{3}{ }^{+}$. Residual solvent and water have been labeled "S" and "W" respectively.

Determination of the association constant (Kass) of $\mathrm{PrNH}_{3}{ }^{+}$toward $1^{-3 \mathrm{H}+, 2 \mathrm{tBuNH} 3+}$. This constant was estimated to be at least $1.2 \times 10^{5} \mathrm{M}^{-1}$ based on the following equilibrium:

$\mathbf{1}^{-3 \mathrm{H}+, 3 \mathrm{tBuNH} 3+}+\mathrm{PrNH}_{2} \rightleftarrows \mathbf{1}^{-3 \mathrm{H}+, 2 \mathrm{tBuNH} 3+} \mathrm{PPrNH}_{3}^{+}$

Kass $=\left[\mathbf{1}^{-3 \mathrm{H}+, \mathbf{2 t B u N H} 3+} \supset \mathbf{P r N H}_{3}{ }^{+}\right] /\left[\mathbf{1}^{-3 \mathrm{H}+, 3 \mathrm{BtBNH} 3+}\right]\left[\mathrm{PrNH}_{2}\right]$

As the ${ }^{1} \mathrm{H}$ NMR spectrum of a 1:1 mixture of $\mathbf{1}^{-3 \mathbf{H}+, 3 \mathrm{tBuNH}+}$ and $\mathrm{PrNH}_{2}$ revealed the formation of $\mathbf{1}^{-3 \mathbf{H}+, 2 \mathrm{tBuNH} 3+}{ } \mathbf{P r N H}_{3}{ }^{+}$as the only observable species (see Fig. S2), the concentrations at the equilibrium of $\mathbf{1}^{-3 \mathrm{H}+, 3 \mathrm{tBuNH}+}$ and $\mathrm{PrNH}_{2}$ have been estimated to be $\leq$ to $0.05 \times \mathrm{C}_{0}$ and the concentration of $\mathbf{1}^{-\mathbf{3 H +}, \mathbf{2 t B u N H} 3+} \supset \mathbf{P r N H}_{3}{ }^{+}$has been estimated to be $\geq$to $0.95 \times \mathrm{C}_{0}$.
Kass $\geq\left[0.95 \times \mathrm{C}_{0}\right] /\left[0.05 \times \mathrm{C}_{0}\right]^{2}$
$\mathrm{C}_{0}=3.2 \times 10^{-3} \mathrm{M}$

Thus, Kass $\geq 1.2 \times 10^{5} \mathrm{M}^{-1}$ 


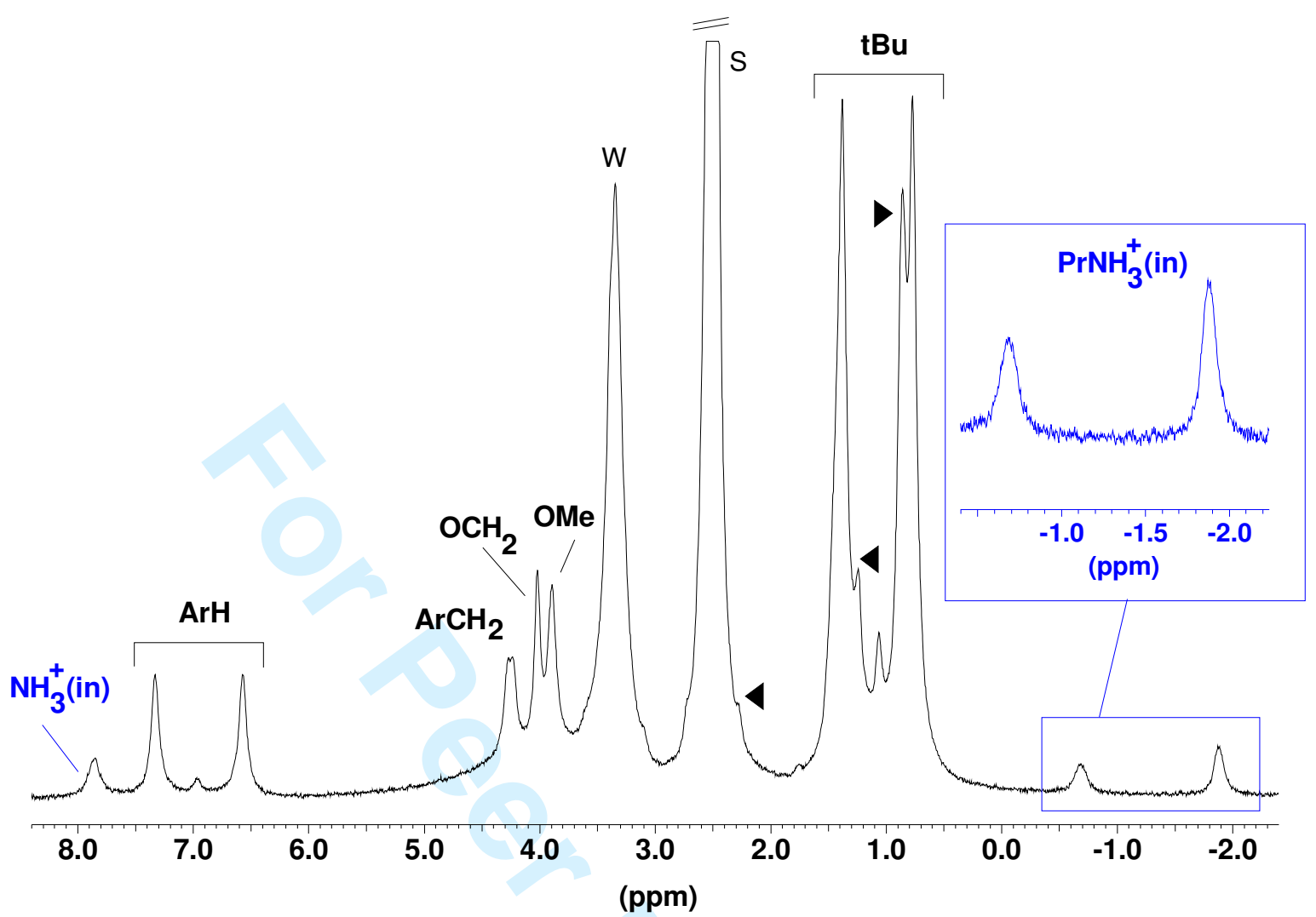

Fig. S3. ${ }^{1} \mathrm{H}$ NMR spectrum (300 MHz, DMSO-d 6 ) at $296 \mathrm{~K}$ of $\mathbf{1}^{-3 \mathbf{H}+, 2 \mathbf{P r N H} 3+}{ }^{+} \mathbf{P r N H}_{3}{ }^{+}$. $\boldsymbol{\nabla}$ : free $\mathrm{PrNH}_{2}$. Residual solvent and water have been labeled "S" and "W" respectively. 


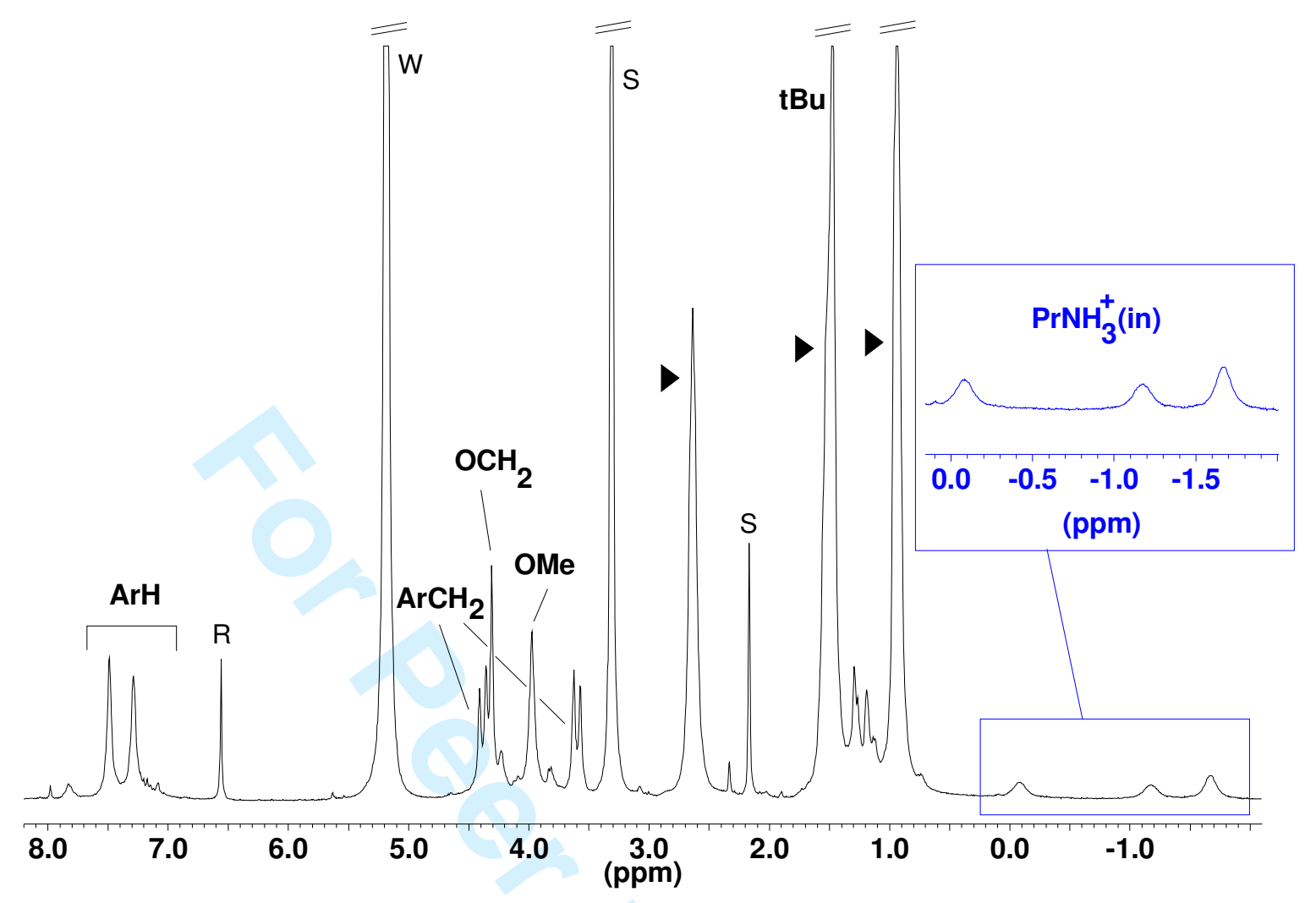

Fig. S4. ${ }^{1} \mathrm{H}$ NMR spectrum $\left(300 \mathrm{MHz}, \mathrm{CD}_{3} \mathrm{OD}\right)$ at $260 \mathrm{~K}$ of $\mathbf{2}^{-\mathbf{3 H +}+\mathbf{2 P r N H}+}{ }^{+} \mathbf{P r N H}_{3}{ }^{+} . \boldsymbol{\nabla}$ : free $\mathrm{PrNH}_{2}$. Residual solvent, reference (1,1,2,2-tetrachloroethane) and water have been labeled "S", "R" and "W" respectively. 


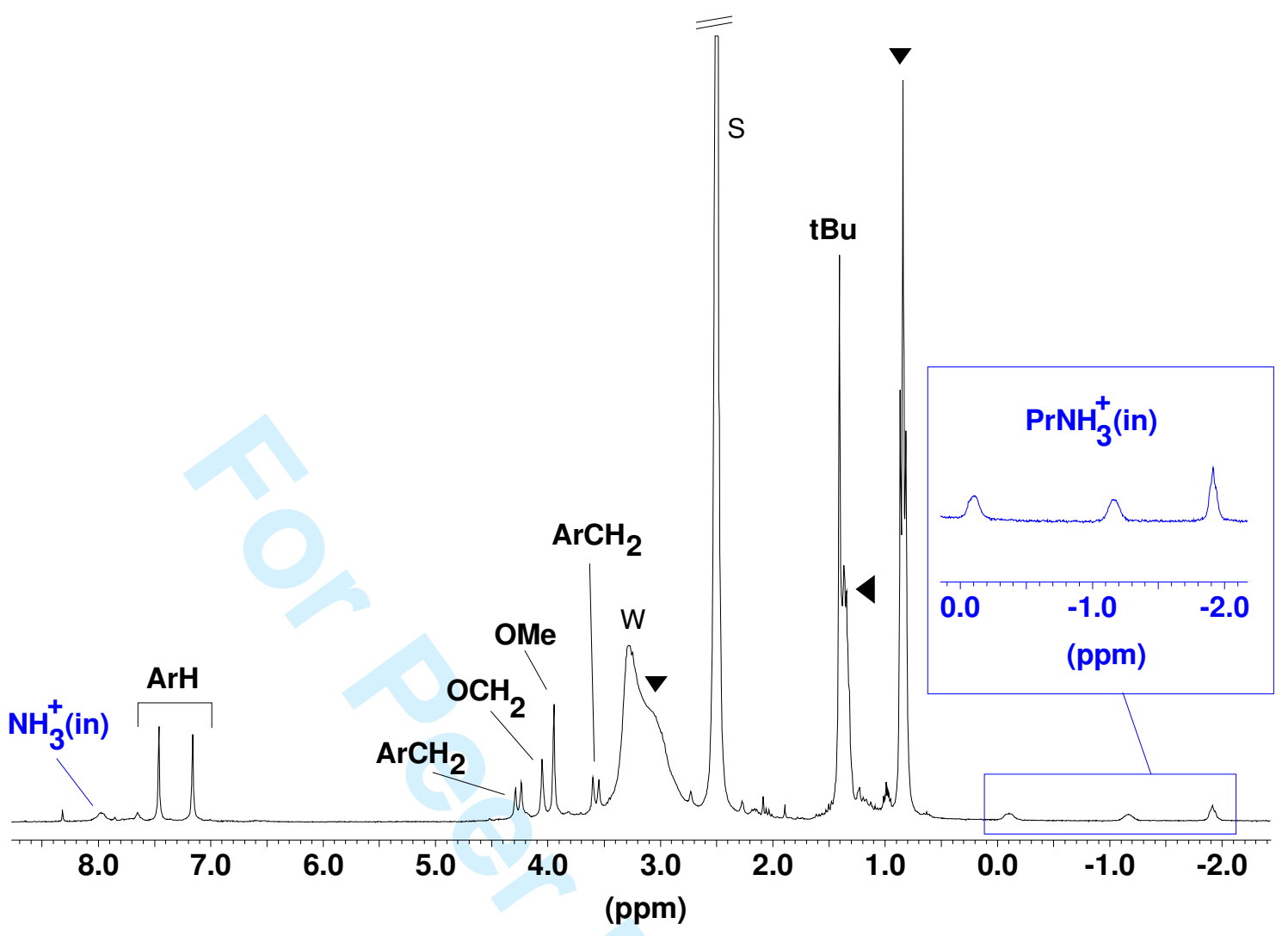

Fig. S5. ${ }^{1} \mathrm{H}$ NMR spectrum (300 MHz, DMSO-d ${ }_{6}$ ) at $295 \mathrm{~K}$ of $\mathbf{2}^{-3 \mathbf{H}+, \mathbf{2 P r N H} 3+}{ }^{3} \mathbf{P r N H}_{3}{ }^{+}$. $\mathbf{\nabla}$ : free $\mathrm{PrNH}_{2}$. Residual solvent and water have been labeled "S" and "W" respectively. 


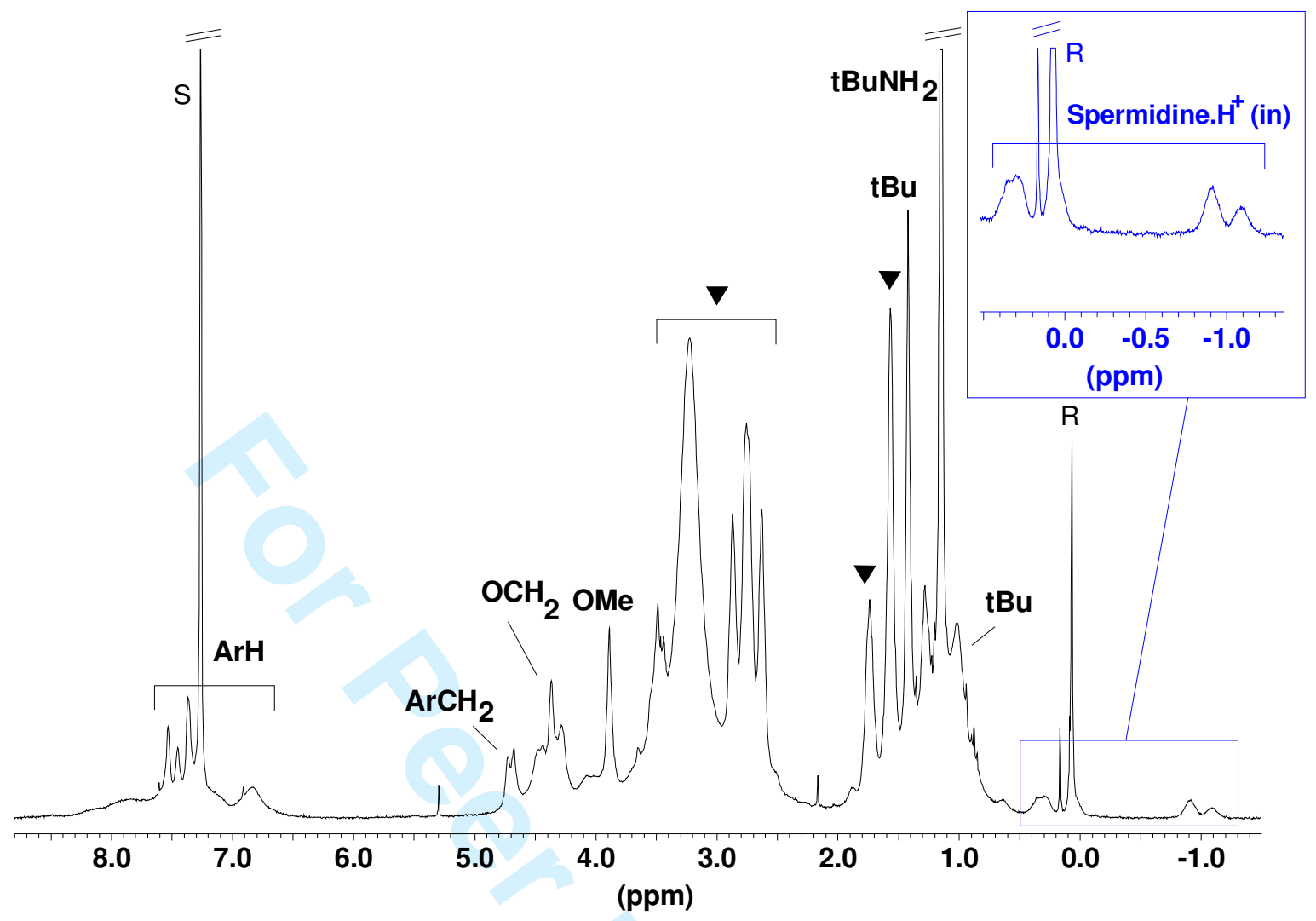

Fig. S6. ${ }^{1} \mathrm{H}$ NMR spectrum $\left(300 \mathrm{MHz}, \mathrm{CDCl}_{3}\right)$ at $294 \mathrm{~K}$ of $\mathbf{2}^{-\mathbf{3 H +}+\mathbf{2 t B u N H}+}{ }^{+}$'spermidine. $\mathbf{H}^{+}$. $\mathbf{\nabla}$ : free spermidine. Residual solvent has been labeled "S". 


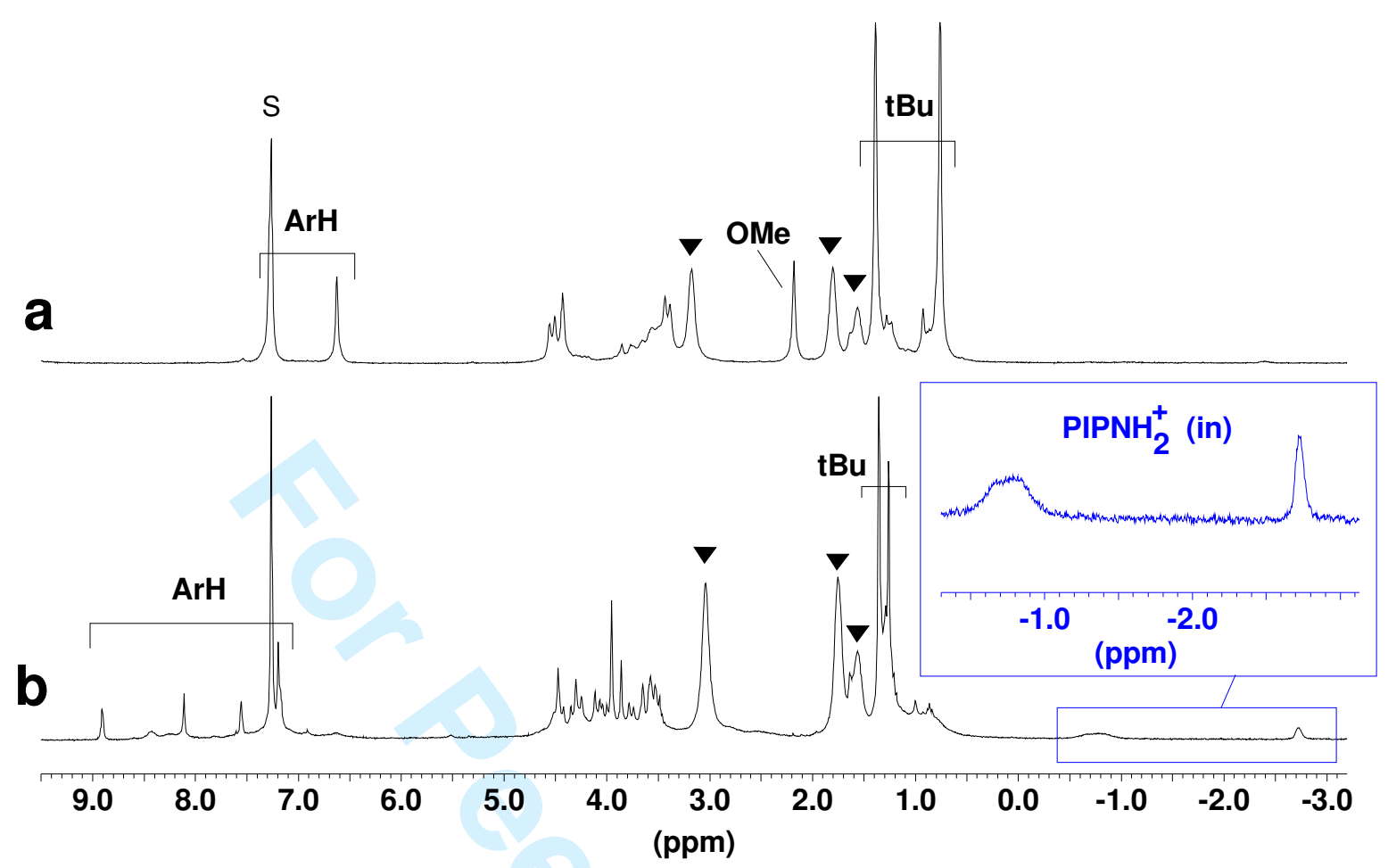

Fig. S7. ${ }^{1} \mathrm{H}$ NMR spectra $\left(300 \mathrm{MHz}, \mathrm{CDCl}_{3}\right)$ at $260 \mathrm{~K}$ of (a): $\mathbf{1}+$ piperidine $(\mathrm{PIPNH})$; (b): $\mathbf{2}^{-}$ ${ }_{3 \mathbf{H}+, 2 \mathbf{P I P N H} 2+}{ } \mathbf{P I P N H}_{2}{ }^{+} ; \boldsymbol{\nabla}$ : free PIPNH. Residual solvent has been labeled "S". 
$1 \mathrm{H}$ NMR spectra (300 MHz, CDCl3) at $294 \mathrm{~K}$ : (a) calix[6]tris-acid 1; (b) Mixture of 1 and 1$2 \mathrm{H}+, \operatorname{PrNH} 3+\mathrm{A}] \quad 1 / 2 \mathrm{PrNH} 3+$ obtained upon the addition of 1 equiv. PrNH2 to 1 ; (c) 1 $2 \mathrm{H}+, \mathrm{PrNH} 3+\hat{\mathrm{A}} \square \quad 1 / 2 \mathrm{PrNH} 3+$ obtained upon the addition of 2 equiv. PrNH2 to 1 ; (d) 1 -

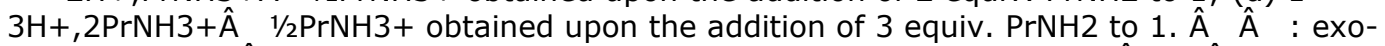
PrNH3+, Âl $¥$ : included PrNH3+. Residual solvent has been labeled $\hat{A} \rrbracket$ gSÂ $\square \mathrm{h}$. $140 \times 91 \mathrm{~mm}(300 \times 300$ DPI $)$ 

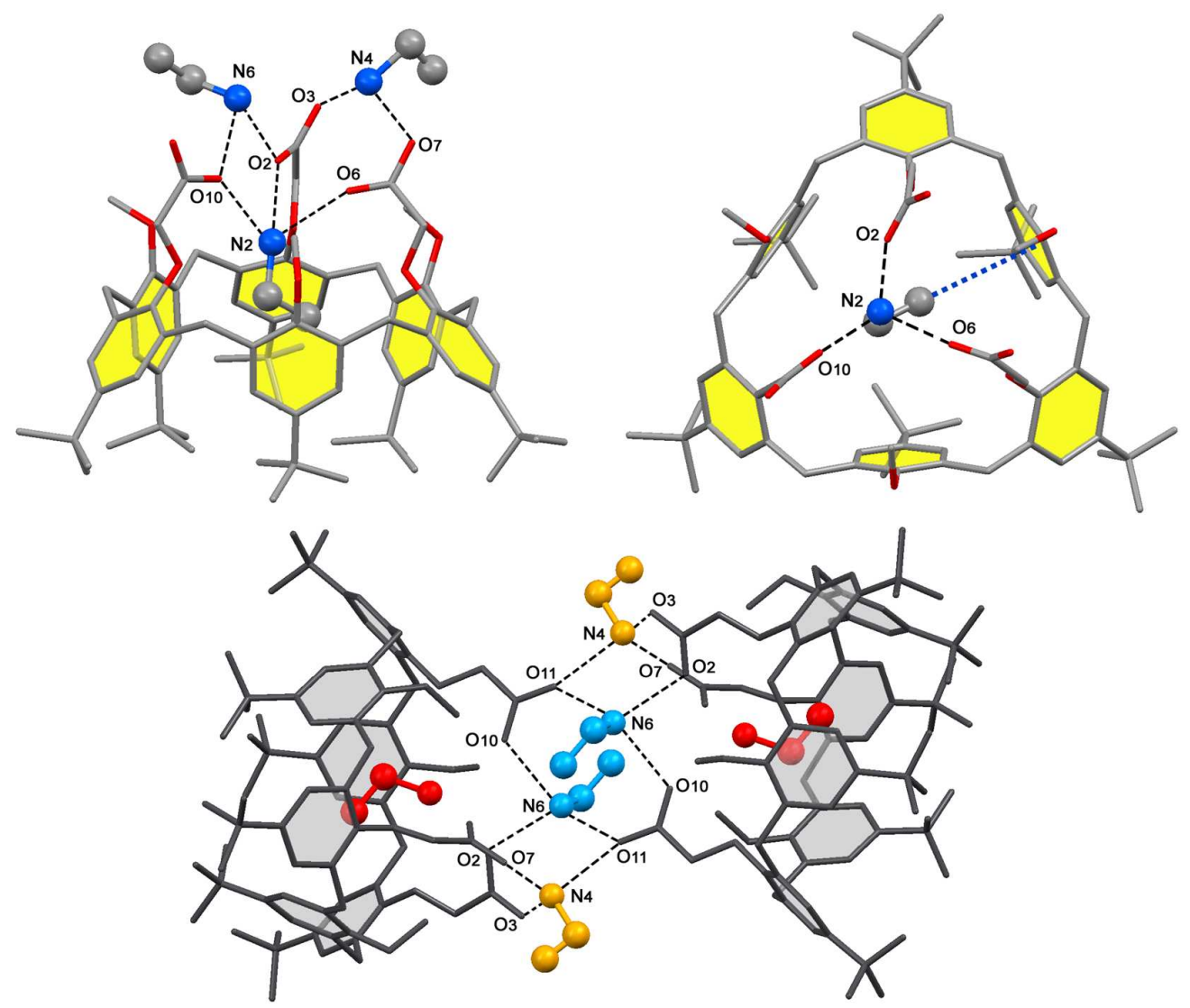

$\mathrm{X}$-ray structure of $1-3 \mathrm{H}+, 2 \mathrm{EtNH} 3+\supset \mathrm{EtNH} 3+$ displaying the $\mathrm{H}$ bonds (dark dashed lines) between the $\mathrm{NH} 3+$ and $\mathrm{COO}$ - groups and the $\mathrm{CH}-\pi$ interaction (blue dashed line) between the methyl group of the guest and an aromatic ring of the host. Hydrogen atoms and solvents of crystallization were omitted for clarity. The calixarene host and the ammonium ions are depicted respectively in capped stick and ball and stick models. Top left: side view of the monomeric subunit. Top right: top view of the monomeric subunit; exo-ammonium ions were omitted for clarity. Bottom: side view of the dimeric assembly; the molecules have been colorized by symmetry equivalence. $140 \times 119 \mathrm{~mm}(300 \times 300 \mathrm{DPI})$ 


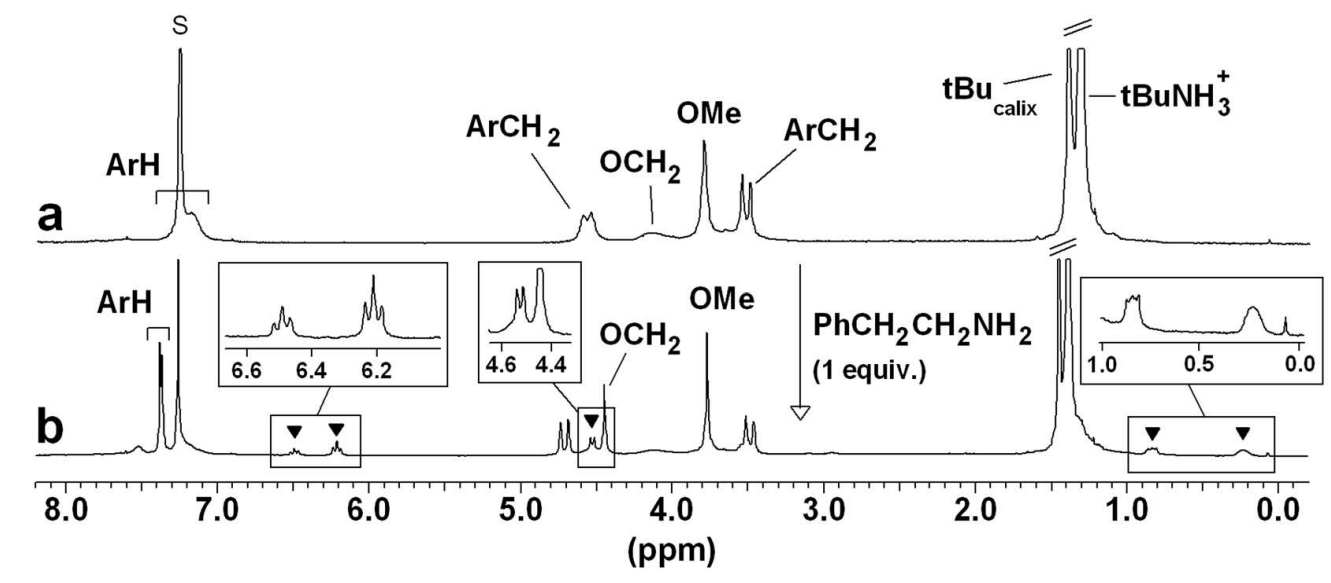

1H NMR spectra (300 MHz, CDCl3) at $294 \mathrm{~K}$. (a) $2-3 \mathrm{H}+, 3 \mathrm{tBuNH} 3+$; (b) $2-$

$3 \mathrm{H}+, 2 \mathrm{tBuNH} 3+\hat{\mathrm{A}}] 1 / 2$ PEANH3 + obtained upon the addition of 1 equiv. of PEANH2 to 2$3 \mathrm{H}+$,3tBuNH3+. Â $¥$ : included PEANH3+. Residual solvent has been labeled Â』 gSÂ』 $\mathrm{h}$. $140 \times 62 \mathrm{~mm}(300 \times 300 \mathrm{DPI})$ 